\title{
Effectiveness of computerized clinical decision support systems for asthma and chronic obstructive pulmonary disease in primary care: a systematic review
}

\author{
Mariam Fathima ${ }^{1,2^{*}}$, David Peiris ${ }^{1,3}$, Pradnya Naik-Panvelkar ${ }^{2}$, Bandana Saini ${ }^{4}$ and Carol Lyn Armour ${ }^{1,2}$
}

\begin{abstract}
Background: The use of computerized clinical decision support systems may improve the diagnosis and ongoing management of chronic diseases, which requires recurrent visits to multiple health professionals, disease and medication monitoring and modification of patient behavior. The aim of this review was to systematically review randomized controlled trials evaluating the effectiveness of computerized clinical decision systems (CCDSS) in the care of people with asthma and COPD.

Methods: Randomized controlled trials published between 2003 and 2013 were searched using multiple electronic databases Medline, EMBASE, CINAHL, IPA, Informit, PsychINFO, Compendex, and Cochrane Clinical Controlled Trials Register databases. To be included, RCTs had to evaluate the role of the CCDSSs for asthma and/or COPD in primary care.

Results: Nineteen studies representing 16 RCTs met our inclusion criteria. The majority of the trials were conducted in patients with asthma. Study quality was generally high. Meta-analysis was not conducted because of methodological and clinical heterogeneity. The use of CCDSS improved asthma and COPD care in 14 of the 19 studies reviewed (74\%). Nine of the nineteen studies showed statistically significant $(p<0.05)$ improvement in the primary outcomes measured. The majority of the studies evaluated health care process measures as their primary outcomes (10/19).

Conclusion: Evidence supports the effectiveness of CCDSS in the care of people with asthma. However there is very little information of its use in COPD care. Although there is considerable improvement in the health care process measures and clinical outcomes through the use of CCDSSs, its effects on user workload and efficiency, safety, costs of care, provider and patient satisfaction remain understudied.
\end{abstract}

Keywords: CCDSS, Computerized clinical decision support systems, Asthma, COPD, Computerized clinical decision making, Systematic review

\section{Background}

Chronic respiratory diseases, particularly asthma and chronic obstructive pulmonary disease (COPD), kill more than four million people every year world-wide and affect hundreds of millions more [1]. Around 300 million people suffer from asthma world-wide, with a projected increase of an additional 100 million people by 2025 [1]. The

\footnotetext{
* Correspondence: mfat5478@uni.sydney.edu.au

'Sydney Medical School, University of Sydney, Sydney, New South Wales, Australia

${ }^{2}$ Woolcock Institute of Medical Research, Sydney Medical School, University of Sydney, Sydney, New South Wales, Australia

Full list of author information is available at the end of the article
}

economic burden of asthma has been estimated to be the highest among chronic diseases [2] and includes both direct (e.g. hospital admissions and costs of medications) and indirect costs (e.g. days away from work) [2,3]. The Global Burden of Disease Study projected that COPD, which ranked sixth as a cause of death in 1990, will become the third leading cause of death in 2030 [4].

Effective management of chronic diseases requires optimal dissemination and implementation of guidelines, however there is a gap between scientific evidence-based medicine and real clinical practice, especially in primary care [5]. Although effective therapies and guidelines are 
available, many patients with asthma still have frequent, uncontrolled symptoms and do not receive optimal care. Research demonstrates that only a quarter of patients with persistent asthma symptoms take anti-inflammatory medications as recommended by the guidelines [6]. Much of the cost of asthma care is attributable to poor disease control due to non-adherence to guideline-recommended controller therapies $[7,8]$, over reliance on reliever medication [9], inadequate monitoring of disease severity and insufficient patient education for effective self-management [10].

Similarly, the care provided for patients with COPD in community settings indicates low level of awareness and implementation of guidelines [11-13], despite the high level of evidence for the efficacy of guideline-based interventions. Medication use is often not in accordance with the guidelines [14] and a high proportion of patients prescribed with inhalers use them incorrectly $[15,16]$. Smoking cessation can reduce the rate of decline in lung function, yet many with COPD continue to smoke. Influenza and pneumococcal vaccinations can reduce the rate of exacerbations, hospitalizations and death [12] However, in Australia, for example, based on the 2004-05 National Health Survey 25\% and 59\% of those with selfreported COPD had never been administered influenza or pneumococcal vaccinations respectively [3].

Globally, studies evaluating the provision of care by clinicians suggest that evidence-based care was delivered approximately $40-55 \%$ of the time [17-19]. The reasons for sub-optimal uptake of guidelines into practice are complex and occur at the patient, provider and system levels [20]. Given, the rising global disease burden from asthma and COPD and intractable health system deficits in providing evidence based care there is a pressing need to identify systems-focused solutions. Computerized Clinical Decision Support System (CCDSS) is well established as one strategic method of improving care for prevention and management of chronic conditions. A CCDSS is "any electronic information system based on a software algorithm designed to aid directly in clinical decision making, in which characteristics of individual patients are used to generate patient-specific assessments or recommendations that are then presented to clinicians for consideration" [21]. CCDSS is valuable not only to the clinicians, but can also provide other health care providers, patients, or caregivers with clinical knowledge and patientspecific information to help them make decisions that enhance patient care [22]. Typically CCDSS interventions include forms and templates for entering and documenting patient information, and alerts, reminders, and order sets for providing suggestions and other support.

Importantly, CCDSS interventions can increase adherence to evidence-based medical knowledge, reduce unnecessary variation in clinical practice and improve their clinical decision-making process $[21,23]$.
CCDS systems that are well designed and implemented have the potential to improve health care quality, increase efficiency by reducing mental workload, improve clinical workflow and reduce health care costs [23,24]. CCDSS has been used in the management of various chronic conditions such as diabetes [25,26], hypertension [27,28], dyslipidemia [29,30] and cardiac care [31] across various health care settings.

Although there have been reviews of the effectiveness of CCDSSs in the management of various disease states in different clinical settings [32,33], there have been no systematic appraisals of their impact on chronic respiratory diseases such as asthma and COPD in primary care. Our systematic review aimed to synthesize evidence for its use in the care of patients with asthma and COPD and to identify the key features of those systems that have the potential to overcome health system barriers and improve outcomes.

\section{Methods}

\section{CCDSS definition}

CCDSS was defined as an automated process for comparing patient-specific characteristics against a computerized knowledge base with resulting recommendations or reminders presented to the provider (or the user) to consider, to help them in clinical decision making.

\section{Search strategy}

The electronic databases MEDLINE, EMBASE, CINAHL, IPA, Informit, PsychINFO, Compendex, and Cochrane Clinical Controlled Trials Register databases were reviewed by the primary author. MeSH terms 'clinical decision support systems/tools/techniques/aids/guidelines', 'computer assisted therapy/diagnosis/decision making,' 'computeris(z) ed decision making,' 'CCDSS,' 'medical informatics', 'asthma', 'COPD' and combinations thereof were included. The detailed search strategy that was used in MEDLINE is outlined in Table 1. This search strategy was repeated in all other databases. We also systematically searched the reference lists of all the included studies and relevant reviews.

\section{Inclusion criteria}

- Empirical studies published in the English language between 2003 to May 2013;

- Pediatric or adult CCDSS interventions involving COPD and/or asthma screening, prevention, case detection, and management;

- Randomized controlled trials comparing CCDSS with explicitly defined clinical or process outcome measures;

- CCDS system used by any clinicians (physicians, physician assistants, pharmacists, dentists, pulmonary specialists or nurse practitioners) directly involved in patient care;

- CCDSS targeting patients in improving self-management. 
Table 1 Search strategy for Medline

\begin{tabular}{|c|c|}
\hline & Search terms used \\
\hline 1. & exp Decision Support Systems, Clinical/ \\
\hline 2. & clinical decision support systems.tw. \\
\hline 3. & clinical decision support tool*.tw. \\
\hline 4. & clinical decision support system*.tw. \\
\hline 5. & Decision Support Techniques/ \\
\hline 6. & Medical Order Entry Systems/ \\
\hline 7. & Decision Making, Computer-Assisted/ \\
\hline 8. & Diagnosis, Computer-Assisted/ \\
\hline 9. & clinical decision support aid*.tw. \\
\hline 10. & clinical decision support guideline*.tw. \\
\hline 11. & computer assisted therap\$.tw. \\
\hline 12. & Therapy, Computer-Assisted/ \\
\hline 13. & reminder system*.tw. \\
\hline 14. & Reminder Systems/ \\
\hline 15. & computeri?ed clinical decision support.tw. \\
\hline 16. & CCDS.tw. \\
\hline 17. & medical informatic*.tw. \\
\hline 18. & Medical Informatics/ \\
\hline 19. & $\begin{array}{l}1 \text { or } 2 \text { or } 3 \text { or } 4 \text { or } 5 \text { or } 6 \text { or } 7 \text { or } 8 \text { or } 9 \text { or } 10 \text { or } 11 \text { or } \\
12 \text { or } 13 \text { or } 14 \text { or } 15 \text { or } 16 \text { or } 17 \text { or } 18\end{array}$ \\
\hline 20. & asthma.mp. or exp Asthmal \\
\hline 21. & exp Pulmonary Disease, Chronic Obstructive/ \\
\hline 22. & chronic obstructive pulmonary disease.tw. \\
\hline 23. & COPD.tw. \\
\hline \multirow[t]{2}{*}{24.} & 20 or 21 or 22 or 23 \\
\hline & 19 and 24 \\
\hline 25. & 19 and 24 \\
\hline 26. & limit 25 to (English language and humans) \\
\hline 27. & limit 26 to yr = "2000-Current" \\
\hline
\end{tabular}

The asterisk (*) represents any group of characters, including no character. The question mark (?) represents any single character. The dollar sign (\$) represents zero or one character (used when searching for expressions).

\section{Exclusion criteria}

- Review articles, conference proceedings, meeting abstracts;

- Paper-based tools (e.g. flow charts and non-electronic clinical pathway tools);

- CCDSS interventions in people with other conditions (rather than asthma and COPD), including other respiratory diseases;

- CCDSS for medical education purposes or only providing summaries of information for patients;

- Group based interventions that did not include individual clinical assessment;
- Evaluations which focused only on the technical performance of the system as opposed to its effect on clinical practice;

- In-patient hospital based systems.

\section{Study selection}

Two authors (MF and PNP) independently reviewed the titles, index terms, and abstracts of the identified references and rated each paper as "potentially relevant" or "not relevant" based on study design, subjects, setting, and intervention. These two authors then independently reviewed the full texts of the selected potentially relevant articles and again rated each paper as "potentially relevant" or "not relevant". After application of the full set of inclusion and exclusion criteria to the potentially relevant studies, a further limitation was then applied, and only RCTs were included. Disagreements between reviewers were resolved by discussion with a third author (CA) until consensus was reached.

\section{Data extraction and quality assessment}

The primary author (MF) independently extracted data related to Participants, Intervention, Comparator, Outcomes and Study design by utilizing the PICOS strategy for describing trials (Table 2). The second author (PNP) then independently examined the studies and extracted data to confirm accuracy. The data abstracted included the following information: manuscript authors, year of publication, the study design and duration, participant characteristics (health practitioners, patients), the type of CCDSS intervention, the comparator (usual care or another form of CDSS) and the outcomes measured (clinical, process, workload and efficiency, economic and implementation). Bias was assessed using the Cochrane risk of bias tool [34], and was based on the following five dimensions: randomization, allocation concealment, blinding of participants, personnel or outcome assessors, selective outcome reporting and completeness of followup [duration of follow-up, intention to treat (ITT) analysis, withdrawals, and reasons for dropouts]. Each of the above attributes was assessed as being high, low or unclear and an overall risk of bias was reached for each of the included studies (Table 3).

\section{Assessment of intervention effects Type of CCDSS intervention provided}

Trials were organized into three categories based on the type of CCDSS intervention provided (Table 4):

1) Diagnostic advice only;

2) Drug therapy management only; and

3) 'Multi-faceted' interventions comprising two or more different intervention components. 
Table 2 Design and characteristics of the included studies

\begin{tabular}{|c|c|c|c|c|c|c|c|}
\hline $\begin{array}{l}\text { Citation, } \\
\text { year, } \\
\text { country }\end{array}$ & $\begin{array}{l}\text { Population: no. of } \\
\text { centers/providers/ } \\
\text { patients } \\
\text { (Intervention, } \\
\text { I or Control, C) }\end{array}$ & $\begin{array}{l}\text { Study design, } \\
\text { setting and } \\
\text { duration }\end{array}$ & Intervention & Comparator & Outcome measures & $\begin{array}{l}\text { Key findings } \\
\text { and effect size }\end{array}$ & Comments \\
\hline $\begin{array}{l}\text { 1. Carroll } \\
\text { et al. [35] } \\
\text { USA. }\end{array}$ & $\begin{array}{l}\text { 1/-/2098 (children } \\
\text { aged 3-11 years) } \\
(\mid=1082, C=1016)\end{array}$ & $\begin{array}{l}\text { RCT, Community } \\
\text { based. Duration: } \\
21 \text { months }\end{array}$ & $\begin{array}{l}\text { Parent survey on } \\
\text { the presence of } \\
\text { asthma symptoms } \\
\text { linked sequentially } \\
\text { to physician prompts. } \\
\text { Physician prompts } \\
\text { mediated by CDSS. }\end{array}$ & $\begin{array}{l}\text { Parents received } \\
\text { no screening } \\
\text { questions, and } \\
\text { physicians } \\
\text { received no } \\
\text { prompts. }\end{array}$ & $\begin{array}{l}\text { Primary outcome: } \\
\text { Physicians' diagnosis } \\
\text { of childhood asthma } \\
\text { based on prompts } \\
\text { by the CDSS. }\end{array}$ & $\begin{array}{l}\text { (+) effect. The } \\
\text { number of children } \\
\text { diagnosed with } \\
\text { asthma in the } \\
\text { intervention group } \\
\text { was significantly } \\
\text { more compared to } \\
\text { the control group } \\
(8.6 \% \text { vs. } 5.8 \% \text {, } \\
\text { P <0.02). Effect } \\
\text { size Cohen's } \\
d=0.24,95 \% \text { C.I = } \\
(0.04-0.43)\end{array}$ & $\begin{array}{l}\text { Not clear } \\
\text { if physician } \\
\text { training was } \\
\text { provided. }\end{array}$ \\
\hline $\begin{array}{l}\text { 2. Hashimoto } \\
\text { et al. [36] } \\
\text { Netherlands }\end{array}$ & $\begin{array}{l}\text { 6/-/95 (adults with } \\
\text { adults diagnosed } \\
\text { with severe asthma) } \\
(I=51, C=38)\end{array}$ & $\begin{array}{l}\text { Pragmatic } \\
\text { Multicentre RCT, } \\
\text { Academic and } \\
\text { community } \\
\text { setting Duration: } \\
6 \text { months }\end{array}$ & $\begin{array}{l}\text { Internet-based } \\
\text { management tool } \\
\text { involving home } \\
\text { monitoring of } \\
\text { symptoms (using } \\
\text { an electronic diary), } \\
\text { treatment decision } \\
\text { support for the patients, } \\
\text { and monitoring support } \\
\text { by a study nurse. }\end{array}$ & $\begin{array}{l}\text { Conventional } \\
\text { asthma } \\
\text { treatment by } \\
\text { pulmonologists }\end{array}$ & $\begin{array}{l}\text { Primary outcome: } \\
\text { Cumulative sparing } \\
\text { of oral corticosteroids, } \\
\text { asthma control using } \\
\text { Asthma control } \\
\text { Questionnaire (ACQ), } \\
\text { asthma-related quality } \\
\text { of life (AQLQ), Second } \\
\text { ary outcomes: FEV1 } \\
\text { (using Piko-1 device), } \\
\text { exacerbations, } \\
\text { hospitalizations and } \\
\text { satisfaction (Global } \\
\text { satisfaction scale) }\end{array}$ & $\begin{array}{l}\text { (+) effect. Median } \\
\text { cumulative sparing } \\
\text { of prednisone was } \\
205 \text { mg in the internet } \\
\text { group compared with } \\
0 \text { mg in the conventional } \\
\text { group. }(P=0.02) \text { Asthma } \\
\text { control, AQLQ, FEV1, } \\
\text { exacerbations, } \\
\text { hospitalizations and } \\
\text { satisfaction with the } \\
\text { strategy were not } \\
\text { different between } \\
\text { groups. Effect size for } \\
\text { CCS sparing } \\
\text { effect: Cohen's } \\
d=0.46 .95 \% \text { C.I = } \\
(0.08-0.93)\end{array}$ & $\begin{array}{l}\text { Patients were } \\
\text { trained in using } \\
\text { the electronic } \\
\text { self -management } \\
\text { support system, } \\
\text { recording } \\
\text { symptoms, } \\
\text { measuring lung } \\
\text { function and } \\
\text { fraction of } \\
\text { exhaled nitric } \\
\text { oxide (FENO) }\end{array}$ \\
\hline $\begin{array}{l}\text { 3. Van der } \\
\text { Meer et al. } \\
\text { [37], Netherlands }\end{array}$ & $\begin{array}{l}37 \text { general practices } \\
\text { and } 1 \text { academic } \\
\text { outpatient department/ } \\
69 / 200 \text { (adults with } \\
\text { asthma) (I=101, } \\
\text { C=99) }\end{array}$ & $\begin{array}{l}\text { Multi-centre, } \\
\text { RCT, Community } \\
\text { and Academic } \\
\text { setting. Duration = } \\
12 \text { months }\end{array}$ & $\begin{array}{l}\text { Internet-based asthma } \\
\text { self-management } \\
\text { program consisting of } \\
\text { weekly asthma control } \\
\text { monitoring and treatment } \\
\text { advice, online support and } \\
\text { group education delivered } \\
\text { via remote web } \\
\text { communications } \\
\text { by a specialized } \\
\text { asthma nurse }\end{array}$ & $\begin{array}{l}\text { Usual physician- } \\
\text { provided } \\
\text { asthma care }\end{array}$ & $\begin{array}{l}\text { Process outcomes: } \\
\text { (asthma knowledge, } \\
\text { inhaler technique and } \\
\text { self-reported medica } \\
\text { tion adherence), health } \\
\text { care provider contacts } \\
\text { for asthma, use of } \\
\text { internet based asthma } \\
\text { monitoring tool, and } \\
\text { medication changes. Clinical } \\
\text { outcomes: Primary: Asthma- } \\
\text { related quality of life, (32-item } \\
\text { Asthma Quality of Life } \\
\text { Questionnaire). Secondary: }\end{array}$ & $\begin{array}{l}\text { (+ but modest effect) } \\
\text { Improvement in asthma } \\
\text { knowledge, inhaler } \\
\text { technique and slightly } \\
\text { fewer physician visits } \\
\text { in the internet group. } \\
\text { Treatment changes } \\
\text { occurred more often } \\
\text { in the internet group. } \\
\text { Modest improvement } \\
\text { in asthma control and } \\
\text { lung function with the } \\
\text { Internet intervention, } \\
\text { but no reduction in }\end{array}$ & $\begin{array}{l}\text { Education and } \\
\text { training provided } \\
\text { to the participants. } \\
\text { Non-blinded } \\
\text { nature of the } \\
\text { study may have } \\
\text { affected } \\
\text { the results }\end{array}$ \\
\hline
\end{tabular}




\begin{tabular}{|c|c|c|c|c|c|}
\hline $\begin{array}{l}\text { 4. Van der } \\
\text { Meer et al. [38] } \\
\text { Netherlands }\end{array}$ & $\begin{array}{l}37 / 69 / 200 \text { (adults } \\
\text { with partly } \\
\text { controlled or } \\
\text { uncontrolled } \\
\text { asthma) } \\
(I=101, C=99)\end{array}$ & $\begin{array}{l}\text { Prospective RCT, } \\
\text { Community } \\
\text { and academic. } \\
\text { Duration: } 1 \text { year }\end{array}$ & $\begin{array}{l}\text { Weekly internet based } \\
\text { self-monitoring (using } \\
\text { ACQ) and subsequent } \\
\text { treatment adjustment } \\
\text { (using an online } \\
\text { management } \\
\text { algorithm) }\end{array}$ & $\begin{array}{l}\text { Usual care by the general } \\
\text { practitioner according } \\
\text { to the Dutch GP } \\
\text { guidelines based on } \\
\text { GINA guidelines }\end{array}$ & $\begin{array}{l}\text { Primary: Asthma } \\
\text { control using } \\
\text { (ACQ), spirometry } \\
\text { and ATAQ (asthma } \\
\text { therapy assessment } \\
\text { questionnaire). }\end{array}$ \\
\hline
\end{tabular}

algorithm)
Asthma control (ACQ)

symptom-free days,

pre-bronchodilator FEV

(Piko-1), daily inhaled

and exacerbations corticosteroid dose

exacerbations

mprovement in

asthma-related quality

of life was slightly

less than clinically

significant. ( $P \geq 0.5$.

Effect size for

the primary clinical

outcome (AQLQ

increase by $>0.5$ :

Cohen's $d=0.6$

$95 \%$ C.I $=(0.3-0.9)$

(+) effect. Significant

improvements in ACQ

score after 12 months

in the internet based

self-monitoring group.

Daily inhaled

corticosteroid

dose significantly

increased in the

Internet group

compared to usual

care in the first 3

months in patients

with uncontrolled

asthma, but not in

patients with well or

partly controlled asthma.

After one year there

were no differences in

daily inhaled

corticosteroid use

or long-acting $\beta 2$-agonists

between the Internet

group and usual care.

Secondary: Mean

daily dose of inhaled

corticosteroid (ICS),

and the proportion

Effect size primary

outcome i.e. chang

in ACQ in partly

controlled asthma

group*: Cohen's

$\mathrm{d}=0.8195 \% \mathrm{C} . \mathrm{I}=$

long-acting $\beta 2$-agonists

(LABA) or leukotriene

receptor antagonists

(0.33- 1.35)

(LTRA).

\section{Effect size for change}

tients were

trained to measure

a hand-held

electronic

spirometer (PiKo1)

Supervision

provided by a nurse

specialist. So there

is heavy initial

investment. Study

outcomes were

self-reported by the

patients which may

overestimate effect

The effect size for

change in asthma

control is quite

large, esp. in the

uncontrolled group

making the

tervention

promising

in ACQ in uncontrolled

asthma group*: Cohen's

$d=0.94 .95 \%$ C.I $=$

(0.38-1.5). *Assuming

t-test was performed. 
Table 2 Design and characteristics of the included studies (Continued)

\begin{tabular}{|c|c|c|c|c|c|c|c|}
\hline $\begin{array}{l}\text { 5. Taylor et al. } \\
\text { [39] Australia. }\end{array}$ & $\begin{array}{l}\text { 3/50/1 (simulated } \\
\text { patient) }(I=27, \\
\mathrm{C}=23 \mathrm{ED} \\
\text { doctors) }\end{array}$ & $\begin{array}{l}\text { RCT, Community } \\
\text { setting, Duration: } \\
4 \text { months }\end{array}$ & $\begin{array}{l}\text { An integrated and } \\
\text { dynamic electronic } \\
\text { decision support } \\
\text { system for } \\
\text { management } \\
\text { of acute asthma } \\
\text { in the emergency } \\
\text { department (ED) } \\
\text { by ED physicians. }\end{array}$ & $\begin{array}{l}\text { Acute asthma } \\
\text { management using } \\
\text { paper -based clinical } \\
\text { records, treatment } \\
\text { order sheets and } \\
\text { discharge } \\
\text { documentation. }\end{array}$ & $\begin{array}{l}\text { Work load \& efficiency } \\
\text { outcomes: Primary: } \\
\text { Quality of asthma } \\
\text { documentation- } \\
\text { measured using } \\
10 \text { documentation } \\
\text { variables (clinical } \\
\text { parameters and } \\
\text { discharge } \\
\text { documentation). } \\
\text { Secondary: } \\
\text { consultation } \\
\text { time }\end{array}$ & $\begin{array}{l}\text { (+) effect. Significantly } \\
\text { higher rates of } \\
\text { documentation } \\
\text { in } 7 \text { out of } 10 \\
\text { variables, including } \\
\text { provision of written } \\
\text { short-term asthma } \\
\text { management plans. } \\
\text { No significant } \\
\text { difference in } \\
\text { consultation times. } \\
\text { Effect size for } \\
\text { documentation } \\
\text { of asthma } \\
\text { management } \\
\text { plan provision: } \\
\text { Cohen's } d=0.78 .95 \% \\
\text { C.I }=(0.18-1.37)\end{array}$ & $\begin{array}{l}\text { Relevant to the ED } \\
\text { setting. A } 2 \text { minute } \\
\text { introduction to the } \\
\text { system, including } \\
\text { basic functions of } \\
\text { the program } \\
\text { provided to } \\
\text { physicians, which } \\
\text { may not be } \\
\text { enough. One } \\
\text { simulated patient } \\
\text { case may not reflect } \\
\text { a spectrum of } \\
\text { scenarios faced in } \\
\text { the ED setting }\end{array}$ \\
\hline $\begin{array}{l}\text { 6. Fiks et al. } \\
\text { [40] USA. }\end{array}$ & $\begin{array}{l}\text { 20/-/11919 } \\
\text { (children } \\
\text { with asthma } \\
\text { between 5-19 years } \\
\text { of age) (I=6110, } \\
\text { C= 5809) }\end{array}$ & $\begin{array}{l}\text { Cluster-RCT, } \\
\text { Academic. } \\
\text { Duration: } \\
5 \text { months. }\end{array}$ & $\begin{array}{l}\text { Electronic health } \\
\text { record (EHR) } \\
\text { based influenza } \\
\text { vaccine clinical } \\
\text { alerts }\end{array}$ & Routine care & $\begin{array}{l}\text { Health care process } \\
\text { outcomes- rates } \\
\text { of captured } \\
\text { opportunities for } \\
\text { influenza vaccination } \\
\text { (visit-level analysis) } \\
\text { and up-to-date } \\
\text { influenza vaccination } \\
\text { status among } \\
\text { patients with } \\
\text { asthma }\end{array}$ & $\begin{array}{l}\text { (+) but modest effect. } \\
\text { Standardized influenza } \\
\text { vaccination rates } \\
\text { improved } 3.4 \% \text { more } \\
\text { at intervention sites } \\
\text { than at control sites. } \\
\text { Effect was not } \\
\text { significant, Cohen's } \\
\text { d not calculated) }\end{array}$ & $\begin{array}{l}\text { Primary care sites } \\
\text { were linked to a } \\
\text { teaching hospital. } \\
\text { Information on the } \\
\text { comparator was } \\
\text { unclear-implied } \\
\text { usual practice. Train } \\
\text { ing provided to the } \\
\text { physicians was } \\
\text { quite thorough. }\end{array}$ \\
\hline $\begin{array}{l}\text { 7. Bell et al. } \\
\text { [41] USA. }\end{array}$ & $\begin{array}{l}\text { 12/-/19450 (children) } \\
(\mathrm{I}=6, \mathrm{C}=6) \text { Children } \\
\text { with persistent } \\
\text { asthma identified by } \\
\text { using the pediatric } \\
\text { asthma control } \\
\text { test }(\mathrm{PACT}))\end{array}$ & $\begin{array}{l}\mathrm{RCT} \text {, Academic } \\
\text { setting. Duration: } \\
1 \text { year }\end{array}$ & $\begin{array}{l}\text { CDSS embedded } \\
\text { in an electronic } \\
\text { health record } \\
\text { (EHR), where it } \\
\text { provides support } \\
\text { in the management } \\
\text { of children with } \\
\text { asthma in accordance } \\
\text { with the (National } \\
\text { Asthma Education } \\
\text { Prevention Program } \\
\text { guidelines (NAEPP). }\end{array}$ & $\begin{array}{l}\text { Passive asthma } \\
\text { management } \\
\text { tools available } \\
\text { in the electronic } \\
\text { health record } \\
\text { (EHR). }\end{array}$ & $\begin{array}{l}\text { Health care process } \\
\text { outcomes: Proportion } \\
\text { of children with at } \\
\text { least } 1 \text { prescription for } \\
\text { controller medication, } \\
\text { an up-to-date asthma } \\
\text { care plan, and } \\
\text { documentation } \\
\text { of performed } \\
\text { office-based } \\
\text { spirometry. }\end{array}$ & $\begin{array}{l}\text { (+) effect. Significant } \\
\text { improvement in } \\
\text { adherence to NAEPP } \\
\text { guidelines. } 6 \% \text { increase } \\
\text { in the number of } \\
\text { prescriptions for } \\
\text { controller medications, } \\
(P=0.006) \text { and } 3 \% \\
\text { increase for spirometry } \\
(P=0.04) \text { in the } \\
\text { intervention urban } \\
\text { practices. Filing an } \\
\text { up-to date asthma care } \\
\text { plan improved } 14 \% \\
\text { ( } P=0.03 \text { ) and spirometry } \\
\text { improved } 6 \% \text { ( } P=0.003) \\
\text { in the suburban practices } \\
\text { with the intervention. The } \\
\text { effect size could not be } \\
\text { calculated, as data }\end{array}$ & $\begin{array}{l}\text { Medical practices } \\
\text { within the Children's } \\
\text { Hospital of } \\
\text { Philadelphia (CHOP) } \\
\text { Pediatric Research } \\
\text { Consortium-may } \\
\text { not be generalizable. } \\
\text { Physicians were } \\
\text { trained to use the } \\
\text { CDSS. The actual } \\
\text { number of } \\
\text { providers involved } \\
\text { in the study } \\
\text { is unclear. }\end{array}$ \\
\hline
\end{tabular}


Table 2 Design and characteristics of the included studies (Continued)

\begin{tabular}{|c|c|c|c|c|c|c|c|}
\hline & & & & & & & \\
\hline $\begin{array}{l}\text { 8. Rasmussen } \\
\text { et al. [42] } \\
\text { Denmark. }\end{array}$ & $\begin{array}{l}-/-/ 300 \text { (adults } \\
\text { with asthma) }\end{array}$ & $\begin{array}{l}\text { Multi-centre } \\
\text { RCT with three } \\
\text { parallel groups. } \\
\text { Community } \\
\text { setting Duration: } \\
6 \text { months }\end{array}$ & $\begin{array}{l}\text { Physician-managed } \\
\text { online interactive } \\
\text { asthma monitoring } \\
\text { tool which comprised } \\
\text { of (1) an electronic } \\
\text { diary, (2) an action } \\
\text { plan for the patients } \\
\text { and (3) a decision } \\
\text { support system for } \\
\text { the physician. Patients } \\
\text { with persistent } \\
\text { asthma received } \\
\text { advice on treatment } \\
\text { based on their } \\
\text { asthma control. }\end{array}$ & $\begin{array}{l}\text { Two other usual } \\
\text { care groups: } \\
\text { specialist group, } \\
\text { where treatment } \\
\text { was provided by } \\
\text { an asthma specialist } \\
\text { in an outpatient } \\
\text { clinic; and a general } \\
\text { practitioner (GP) } \\
\text { group, where } \\
\text { treatment was } \\
\text { provided by } \\
\text { GPs in } \\
\text { primary care. }\end{array}$ & $\begin{array}{l}\text { Clinical outcomes } \\
\text { Asthma symptoms: } \\
\text { electronic diary. } \\
\text { Asthma quality of } \\
\text { life: AQLQ) } \\
\text { questionnaire. Lung } \\
\text { function: Spirometry } \\
\text { Airway responsiveness: } \\
\text { Methacholine } \\
\text { challenge test. }\end{array}$ & $\begin{array}{l}\text { (+) effect. Significant } \\
\text { improvement in the } \\
\text { Internet group } \\
\text { compared to the other } \\
2 \text { groups regarding } \\
\text { asthma symptoms, } \\
\text { quality of life, lung } \\
\text { function, airway } \\
\text { responsiveness. Significant } \\
\text { improvement in the use } \\
\text { of inhaled corticosteroids } \\
\text { in the internet and } \\
\text { specialist group. Effect } \\
\text { size comparing the } \\
\text { Internet vs. Specialist } \\
\text { group for asthma } \\
\text { symptom reduction } \\
\text { was Cohen's } d=0.53 \text {. } \\
95 \% \text { C.I = (0.19-0.87). } \\
\text { Cohen's d comparing } \\
\text { the Internet vs. GP group } \\
\text { for asthma symptom } \\
\text { reduction was } 0.64 \text {. } \\
95 \% \text { C.I = (0.29-0.99). }\end{array}$ & $\begin{array}{l}\text { The number of } \\
\text { practitioners and } \\
\text { the number of } \\
\text { centers participating } \\
\text { were unclear. No } \\
\text { training provided } \\
\text { to the participants } \\
\text { or the GP's but the } \\
\text { laboratory assistants } \\
\text { providing spirometry } \\
\text { and methacholine } \\
\text { test were trained } \\
\text { in the required } \\
\text { protocol }\end{array}$ \\
\hline $\begin{array}{l}\text { 9. Dexheimer } \\
\text { et al. [43] USA. }\end{array}$ & $\begin{array}{l}\text { 1/-/704 (Children } \\
2-18 \text { years of age), } \\
(I=358, C=346)\end{array}$ & $\begin{array}{l}\mathrm{RCT} \text {, Community } \\
\text { setting, Duration: } \\
3 \text { months }\end{array}$ & $\begin{array}{l}\text { A fully computerized } \\
\text { asthma detection } \\
\text { system which } \\
\text { printed a paper- } \\
\text { based asthma } \\
\text { care protocol in } \\
\text { the pediatric ED } \\
\text { to guide early } \\
\text { asthma treatment } \\
\text { and reduce time to } \\
\text { disposition decision. }\end{array}$ & $\begin{array}{l}\text { Usual care, i.e., } \\
\text { no reminders or } \\
\text { automatic printout } \\
\text { was provided. }\end{array}$ & $\begin{array}{l}\text { Primary outcome: } \\
\text { Time from ED triage } \\
\text { to disposition } \\
\text { (discharge or } \\
\text { hospital admission) } \\
\text { decision. } \\
\text { Secondary outcomes: } \\
\text { Guideline adherence } \\
\text { measures including } \\
\text { asthma education } \\
\text { ordered, protocol } \\
\text { found on chart, any } \\
\text { asthma scoring } \\
\text { performed. }\end{array}$ & $\begin{array}{l}\text { No effect. No difference } \\
\text { in time to disposition. } \\
\text { Length of ED stay } \\
\text { and the rate of hospital } \\
\text { admission were similar } \\
\text { between the two groups. } \\
\text { (Effect was not significant, } \\
\text { Cohen's d not calculated) }\end{array}$ & $\begin{array}{l}\text { The number of } \\
\text { physicians, respiratory } \\
\text { therapists and nurses } \\
\text { involved in the } \\
\text { study is unclear. }\end{array}$ \\
\hline $\begin{array}{l}\text { 10. Smith } \\
\text { et al. [44] UK. }\end{array}$ & $\begin{array}{l}29 /-/ 911 \text { (patients } \\
5+\text { years of age } \\
\text { with severe asthma) } \\
(I=457, C=454)\end{array}$ & $\begin{array}{l}\text { Cluster } \mathrm{RCT} \text {, } \\
\text { Community } \\
\text { setting. Duration: } \\
2.5 \text { years }\end{array}$ & $\begin{array}{l}\text { Addition of electronic } \\
\text { alerts to computerized } \\
\text { records to identify } \\
\text { at-risk asthma patients } \\
\text { experiencing an } \\
\text { exacerbation } \\
\text { and modify } \\
\text { their care. }\end{array}$ & $\begin{array}{l}\text { Control practices } \\
\text { continued } \\
\text { usual care. }\end{array}$ & $\begin{array}{l}\text { Primary outcome: } \\
\text { number of patients } \\
\text { experiencing a } \\
\text { moderate-severe } \\
\text { exacerbation } \\
\text { Secondary outcome: } \\
\text { outpatient attendances } \\
\text { for asthma, primary } \\
\text { care contacts, 'did }\end{array}$ & $\begin{array}{l}\text { No significant difference } \\
\text { between groups } \\
\text { in number of people } \\
\text { experiencing } \\
\text { exacerbations. } \\
\text { Relative reductions } \\
\text { in people experiencing } \\
\text { hospitalizations, accident } \\
\text { and emergency, out-of }\end{array}$ & $\begin{array}{l}\text { Training on using } \\
\text { electronic alerts } \\
\text { provided to at least } \\
\text { one representative } \\
\text { from each staff } \\
\text { group (GP, nurse, } \\
\text { receptionist, manager/ } \\
\text { administrator, dispenser) }\end{array}$ \\
\hline
\end{tabular}

provided was insufficient

asthma symptom

effect. No difference

me to disposition.

Secondary outcomes:

Guideline adherence

ordered, protocol

und on chart, any

o significant difference

xperiencing

Relative reductions

hospitalizations, accident

for asthma, pim

care contacts, 'did 
Table 2 Design and characteristics of the included studies (Continued)

\begin{tabular}{|c|c|c|c|c|c|c|c|}
\hline & & & & & $\begin{array}{l}\text { not attends' (DNAs) } \\
\text { at consultations, } \\
\text { asthma medications } \\
\text { and cost analyses }\end{array}$ & $\begin{array}{l}\text { hours contacts and } \\
\text { increase in prednisolone } \\
\text { prescriptions for } \\
\text { exacerbations without } \\
\text { increasing costs. (Effect } \\
\text { was not significant, } \\
\text { Cohen's d not } \\
\text { calculated) }\end{array}$ & $\begin{array}{l}\text { of the intervention } \\
\text { practices. }\end{array}$ \\
\hline $\begin{array}{l}\text { 11. Kattan } \\
\text { et al. [45] USA. }\end{array}$ & $\begin{array}{l}\text {-/435/937 (5-11year } \\
\text { old with moderate } \\
\text { to severe asthma) } \\
(I=471, C=468)\end{array}$ & $\begin{array}{l}\text { RCT, Community } \\
\text { setting. Duration: } \\
1 \text { year }\end{array}$ & $\begin{array}{l}\text { Computer generated } \\
\text { letters based on } \\
\text { information collected } \\
\text { from the child's carer } \\
\text { through bi-monthly } \\
\text { telephone calls } \\
\text { conducted by the } \\
\text { centralized service } \\
\text { for all the study sites. } \\
\text { The letter to the } \\
\text { physician caring for that } \\
\text { child summarized the } \\
\text { child's asthma symptoms, } \\
\text { health service use, and } \\
\text { medication use with a } \\
\text { corresponding } \\
\text { recommendation to } \\
\text { step up or step down } \\
\text { medications in } \\
\text { accordance with the } \\
\text { NAEPP guidelines. }\end{array}$ & $\begin{array}{l}\text { No letters sent to } \\
\text { the providers of } \\
\text { the children in } \\
\text { the control group }\end{array}$ & $\begin{array}{l}\text { Health care process } \\
\text { outcomes: scheduled } \\
\text { visits and changes in } \\
\text { medications. Patient } \\
\text { outcomes: maximum } \\
\text { number of symptom } \\
\text { days, ED visits and } \\
\text { hospitalizations } \\
\text { for asthma, and } \\
\text { school days missed } \\
\text { because of asthma. }\end{array}$ & $\begin{array}{l}\text { (+) effect Significant } \\
\text { increase in scheduled } \\
\text { visits, }(17.1 \% \text { vs } 12.3 \% \text {, } \\
P=0.005) \text {. Significant } \\
\text { increase in medication } \\
\text { step up ( } 46 \% \text { vs } 35.6 \% \text {, } \\
P=0.03) \text {. Significantly } \\
\text { fewer ED visits in the } \\
\text { intervention group } \\
\text { compared with controls } \\
\text { ( } 0.87 \text { vs } 1.14 \text { per year, } \\
p=0.013) \text {. No difference } \\
\text { in the maximum number } \\
\text { of symptom days and } \\
\text { number of school days } \\
\text { missed. Effect size for } \\
\% \text { of scheduled visits } \\
\text { resulting in step-up of } \\
\text { medication: Cohen's } \\
d=0.23 .95 \% \\
C . I=(0.02-0.43)\end{array}$ & $\begin{array}{l}\text { Intervention } \\
\text { practitioners were } \\
\text { trained. Effect size } \\
\text { was low for } \\
\text { medication change } \\
\text { related outcomes. } \\
\text { Key issues also } \\
\text { included the design } \\
\text { where not all children } \\
\text { whose medication } \\
\text { change was } \\
\text { warranted visited } \\
\text { the physician. }\end{array}$ \\
\hline $\begin{array}{l}\text { 12. Tierney } \\
\text { et al. [46] USA. }\end{array}$ & $\begin{array}{l}4 / 266 / 706 \\
\text { ( } 246 \text { physicians } \\
\text { and } 20 \text { outpatient } \\
\text { pharmacists) }\end{array}$ & $\begin{array}{l}\text { RCT, Academic } \\
\text { setting, Duration: } \\
3 \text { years }\end{array}$ & $\begin{array}{l}\text { Computerized care } \\
\text { suggestions to } \\
\text { improve asthma and } \\
\text { COPD management. } \\
\text { These focused on: (1) } \\
\text { pulmonary function } \\
\text { tests, (2) influenza and } \\
\text { pneumococcal vaccinations, } \\
\text { (3) prescribing inhaled } \\
\text { steroid preparations in } \\
\text { patients with frequent } \\
\text { symptoms of dyspnea, } \\
\text { (4) prescribing inhaled } \\
\text { anticholinergic agents in } \\
\text { patients with COPD, } \\
\text { (5) escalating doses of } \\
\text { inhaled } \beta \text {-agonists for all } \\
\text { patients with persistent } \\
\text { symptoms, (6) prescribing } \\
\text { theophylline for patients } \\
\text { with COPD and continued }\end{array}$ & $\begin{array}{l}\text { Four groups: } \\
\text { physician } \\
\text { intervention } \\
\text { only, pharmacist } \\
\text { intervention only, } \\
\text { both pharmacist } \\
\text { and physician } \\
\text { interventions, and } \\
\text { no intervention } \\
\text { (controls). }\end{array}$ & $\begin{array}{l}\text { Primary: Adherence } \\
\text { to guideline based } \\
\text { care suggestions. } \\
\text { Secondary: Quality of } \\
\text { life-McMaster Chronic } \\
\text { Respiratory Disease } \\
\text { Questionnaire (CRQ) } \\
\text { for COPD patients or } \\
\text { the McMaster Asthma } \\
\text { Quality-of-Life. } \\
\text { Questionnaire (AQLQ). } \\
\text { Patient satisfaction: } \\
\text { American Board of } \\
\text { Internal Medicine's } \\
\text { patient satisfaction } \\
\text { questionnaire. } \\
\text { Medication } \\
\text { adherence: Inui and } \\
\text { Morisky surveys and } \\
\text { pharmacy dispensing }\end{array}$ & $\begin{array}{l}\text { No effect. No } \\
\text { differences } \\
\text { between groups in } \\
\text { adherence to the } \\
\text { care suggestions, } \\
\text { quality of life, } \\
\text { patients satisfaction } \\
\text { with physicians' or } \\
\text { pharmacists, medication } \\
\text { compliance, emergency } \\
\text { department visits, or } \\
\text { hospitalizations. } \\
\text { Physicians receiving } \\
\text { the intervention had } \\
\text { significantly higher } \\
\text { total health care costs. } \\
\text { Physician attitudes } \\
\text { toward guidelines were } \\
\text { mixed. (Effect was not } \\
\text { significant, Cohen's d } \\
\text { not calculated) }\end{array}$ & $\begin{array}{l}\text { Hospital based } \\
\text { academic practices. } \\
\text { Providers included } \\
\text { internal medicine } \\
\text { physicians, residents } \\
\text { and pharmacists. } \\
\text { Training was provided } \\
\text { to the providers. } \\
\text { Questionnaires were } \\
\text { administered via } \\
\text { telephone. }\end{array}$ \\
\hline
\end{tabular}

physician caring for tha

child summarized the

ealth senvice use, and

corresponding

medications in

NAEPP guidelines.

Four groups:

physician

only, pharmacist 
Table 2 Design and characteristics of the included studies (Continued)

\begin{tabular}{|c|c|c|c|c|c|c|c|}
\hline & & & $\begin{array}{l}\text { symptoms despite } \\
\text { aggressive use of inhaled } \\
\text { anticholinergic agents, } \\
\text { b-agonists, and steroids, } \\
\text { and (7) encouraging } \\
\text { smoking cessation. }\end{array}$ & & & & \\
\hline $\begin{array}{l}\text { 13. Martens } \\
\text { et al. [47] } \\
\text { Netherlands. }\end{array}$ & $-/ 53 /-$ & $\begin{array}{l}\text { Clustered RCT, } \\
\text { Community } \\
\text { setting Duration: } \\
1 \text { year }\end{array}$ & $\begin{array}{l}\text { A decision support } \\
\text { system with reactive } \\
\text { computer reminders } \\
\text { (CRS) to improve drug } \\
\text { prescribing behaviors. } \\
25 \mathrm{GPs} \text { received } \\
\text { reminders on antibiotics } \\
\text { and asthma/COPD } \\
\text { prescriptions. }\end{array}$ & $\begin{array}{l}28 \text { GPs received } \\
\text { reactive computer } \\
\text { reminders (CRS) } \\
\text { to improve } \\
\text { prescribing of } \\
\text { cholesterol- } \\
\text { lowering drugs }\end{array}$ & $\begin{array}{l}\text { Primary outcome: } \\
\text { prescription } \\
\text { according to the } \\
\text { guidelines as a } \\
\text { percentage of total } \\
\text { prescriptions of a } \\
\text { certain drug. } \\
\text { Secondary outcome: } \\
\text { user friendliness. }\end{array}$ & $\begin{array}{l}\text { (+) but not significant } \\
\text { effect. CRS with reactive } \\
\text { reminders improved } \\
\text { drug prescribing } \\
\text { behavior. Preliminary } \\
\text { results also indicate } \\
\text { reduction in the } \\
\text { number of prescriptions } \\
\text { according to the advice } \\
\text { of the computerized } \\
\text { guidelines not to } \\
\text { present certain drugs. } \\
\text { It was perceived stable } \\
\text { and user friendly. (Effect } \\
\text { was not significant, } \\
\text { Cohen's d not } \\
\text { calculated) }\end{array}$ & $\begin{array}{l}\text { Preliminary study. } \\
\text { Both groups served } \\
\text { as control to one } \\
\text { another. Not specific } \\
\text { to asthma/COPD. }\end{array}$ \\
\hline $\begin{array}{l}\text { 14. Martens } \\
\text { et al. [48] } \\
\text { Netherlands. } \\
\text { Follow-up of } \\
\text { the above study }\end{array}$ & 14/53/- & $\begin{array}{l}\text { Clustered RCT, } \\
\text { Community } \\
\text { setting. Duration: } \\
1 \text { year }\end{array}$ & $\begin{array}{l}\text { CRS focused on } \\
\text { drug-prescribing } \\
\text { behavior of GPS. } \\
25 \text { GPs received } \\
\text { reminders on } \\
\text { antibiotics and } \\
\text { asthma/COPD } \\
\text { prescriptions }\end{array}$ & $\begin{array}{l}28 \text { GPs received CRS } \\
\text { reminders on } \\
\text { cholesterol } \\
\text { prescriptions }\end{array}$ & $\begin{array}{l}\text { Guideline appropriate } \\
\text { prescriptions as a } \\
\text { percentage of total } \\
\text { prescriptions (of the } \\
\text { drug category } \\
\text { involved) for the } \\
\text { same diagnosis on } \\
\text { the individual GP } \\
\text { level. Absolute number } \\
\text { of prescriptions for a } \\
\text { specific diagnosis per } \\
\text { GP per } 1000 \\
\text { enlisted patients. }\end{array}$ & $\begin{array}{l}\text { No effect. No favorable } \\
\text { effects were found for } \\
\text { CRS with the message } \\
\text { to prescribe certain } \\
\text { drugs. On the other } \\
\text { hand, CRS with the } \\
\text { message not to } \\
\text { prescribe certain } \\
\text { drugs sometimes } \\
\text { positively influenced } \\
\text { the prescribing } \\
\text { behavior of GPs. } \\
\text { (Effect was not } \\
\text { significant, Cohen's d } \\
\text { not calculated) }\end{array}$ & $\begin{array}{l}\text { Not specific to } \\
\text { asthma/COPD. Both } \\
\text { groups served as a } \\
\text { control group to } \\
\text { one another. Authors } \\
\text { report the study to } \\
\text { be underpowered } \\
\text { due to high inter } \\
\text { doctor variation in } \\
\text { prescribing behavior } \\
\text { (Cluster effect). } \\
\text { Training was provided. }\end{array}$ \\
\hline $\begin{array}{l}\text { 15. Martens } \\
\text { et al. [49] } \\
\text { Netherlands. } \\
\text { Follow-up of } \\
\text { the above study. }\end{array}$ & 20/48/- & $\begin{array}{l}\text { Clustered RCT, } \\
\text { Community } \\
\text { setting. Duration: } \\
1 \text { year }\end{array}$ & $\begin{array}{l}25 \text { GPs received } \\
\text { reactive computer } \\
\text { reminders on } \\
\text { antibiotics and } \\
\text { asthma/COPD } \\
\text { prescriptions }\end{array}$ & $\begin{array}{l}28 \text { GPs received } \\
\text { (reactive) reminders on } \\
\text { cholesterol } \\
\text { prescriptions }\end{array}$ & $\begin{array}{l}\text { Number of GPs } \\
\text { (competent and willing) } \\
\text { with CRS still functioning } \\
\text { after } 1 \text { year. Number of } \\
\text { GPs having technical } \\
\text { problems or are } \\
\text { unwilling. Number of } \\
\text { reminders/GP/month/ } \\
1000 \text { enlisted patients. } \\
\text { GP user satisfaction } \\
\text { (satisfaction questionnaire). } \\
\text { GP experience (content }\end{array}$ & $\begin{array}{l}\text { (+) learning effect } \\
\text { from the CRS. } 9 \% \\
\text { of GPs dropped out } \\
\text { after } 1 \text { year. A significant } \\
\text { learning curve was } \\
\text { found }(P=0.03) \text { for } \\
\text { the reminders on } \\
\text { antibiotics, asthma } \\
\text { and COPD. GPs were } \\
\text { satisfied with the } \\
\text { user-friendliness and } \\
\text { the content of the }\end{array}$ & $\begin{array}{l}\text { Not specific to } \\
\text { asthma/COPD. Both } \\
\text { groups served as a } \\
\text { control to one } \\
\text { another. GP's } \\
\text { were trained. }\end{array}$ \\
\hline
\end{tabular}

(+) but not significant effect. CRS with reactive and user friendly. (Effect was not significant with the message message not to significant, Cohen's d
Preliminary study. as control to one nother. Not specific

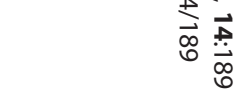
asthma/COPD. Both groups served as a control group to

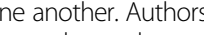
be underpowered due to high inter prescribing behavior (Cluster effect).

ot specific to asthma/COPD. Both control to one another. GP's 
Table 2 Design and characteristics of the included studies (Continued)

\begin{tabular}{|c|c|c|c|c|c|c|c|}
\hline $\begin{array}{l}\text { 16. Kuilboer } \\
\text { et al. [50] } \\
\text { Netherlands. }\end{array}$ & $\begin{array}{l}32 / 40 / 156,772 \\
\text { (study patients } \\
\text { (children and } \\
\text { adults) either had } \\
\text { chronic bronchitis, } \\
\text { emphysema, other } \\
\text { chronic pulmonary } \\
\text { diseases, asthma or } \\
\text { COPD) (I =20, C=20 } \\
\text { General practitioners) }\end{array}$ & $\begin{array}{l}\text { RCT, Community } \\
\text { and academic } \\
\text { Duration: } \\
10 \text { months }\end{array}$ & $\begin{array}{l}\text { Asthma Critic used } \\
\text { for monitoring and } \\
\text { treatment of patients } \\
\text { with asthma and } \\
\text { COPD by Dutch } \\
\text { general practitioners } \\
\text { in daily practice. The } \\
\text { asthma critic was a } \\
\text { computer software } \\
\text { support program } \\
\text { that presented a } \\
\text { patient specific } \\
\text { comment to the } \\
\text { physician based on } \\
\text { the current } \\
\text { clinical situation. }\end{array}$ & Usual care & $\begin{array}{l}\text { Average number of } \\
\text { contacts, FEV1 } \\
\text { (force expiratory } \\
\text { volume) and peak } \\
\text { flow measurements } \\
\text { per asthma/COPD } \\
\text { patient per practice, } \\
\text { and the average } \\
\text { number of } \\
\text { antihistamine, } \\
\text { cromogylate, } \\
\text { deptropine, and } \\
\text { oral bronchodilator } \\
\text { prescriptions per } \\
\text { asthma/COPD } \\
\text { patient per practice. }\end{array}$ & $\begin{array}{l}(+) \text { effect. Statistically } \\
\text { significant increase in } \\
\text { contact frequency with } \\
\text { the patient }(P=0.034) \text {, } \\
\text { peak flow measurement, } \\
\mathrm{FEV}_{1} \text { measurements in } \\
12-39 \text { years age group } \\
(\mathrm{P}=0.02) \text {. Significant } \\
\text { decrease in cromogylate } \\
\text { prescriptions in the } \\
\text { age group of 12-39 } \\
\text { years, }(\mathrm{P}=0.03) \text {. } \\
\text { Non-significant decrease } \\
\text { in deptropine, } \\
\text { antihistamines, oral } \\
\text { bronchodilators. } \\
\text { (Effect size not calculable } \\
\text { due to insufficient data } \\
\text { provided in report). }\end{array}$ & $\begin{array}{l}\text { The study focused } \\
\text { on change in } \\
\text { physicians' behavior. } \\
\text { Training was } \\
\text { provided to the } \\
\text { general practitioners. }\end{array}$ \\
\hline $\begin{array}{l}\text { 17. Poels } \\
\text { et al. [51] } \\
\text { Netherlands }\end{array}$ & $\begin{array}{l}1 \text { medical centre, } \\
\text { several private } \\
\text { practices/78/774 } \\
\text { paper case } \\
\text { descriptions. } \\
\text { (10 case } \\
\text { descriptions } \\
\text { per GP). }\end{array}$ & $\begin{array}{l}\text { Simulated } \\
\text { cluster- } R C T \\
\text { Community. } \\
\text { Duration }=10 \\
\text { months }\end{array}$ & $\begin{array}{l}\text { Expert support system } \\
\text { for the interpretation } \\
\text { of spirometry tests } \\
\text { to help GPs' in the } \\
\text { diagnosis of chronic } \\
\text { respiratory diseases. } \\
\text { The expert system } \\
\text { provided interpretation } \\
\text { in the form of flow } \\
\text { volume curve, } \\
\text { graphical interpretation } \\
\text { and textual interpretative } \\
\text { notes of spirometry } \\
\text { results to } \\
\text { intervention GPs. }\end{array}$ & $\begin{array}{l}\text { GPs in the control } \\
\text { group simply } \\
\text { received the } \\
\text { spirometry test } \\
\text { results, and the } \\
\text { flow-volume } \\
\text { and volume-time } \\
\text { curves. }\end{array}$ & $\begin{array}{l}\text { Primary: Difference } \\
\text { between the } \\
\text { percentage agreement } \\
\text { of the cases' diagnoses } \\
\text { between GPs and } \\
\text { expert panel judgment } \\
\text { before and after } \\
\text { interpretation of } \\
\text { spirometry } \\
\text { Secondary: Impact of } \\
\text { the expert system } \\
\text { intervention on the } \\
\text { GPs decision-making } \\
\text { processes through six } \\
\text { measures: additional } \\
\text { diagnostic test rates; } \\
\text { width of differential } \\
\text { diagnosis; certainty of } \\
\text { diagnosis; estimated }\end{array}$ & $\begin{array}{l}\text { No Effect. There were } \\
\text { no differences between } \\
\text { the computerized } \\
\text { expert support and } \\
\text { control groups in } \\
\text { the agreement between } \\
\text { GPs and expert panel } \\
\text { on diagnosis of COPD, } \\
\text { asthma and absence } \\
\text { of respiratory disease. } \\
\text { A higher rate of } \\
\text { additional diagnostic } \\
\text { tests was observed } \\
\text { in the expert support } \\
\text { group. (Effect was not } \\
\text { significant, Cohen's d } \\
\text { not calculated) }\end{array}$ & $\begin{array}{l}\text { This was a simulated } \\
\text { study- no real patients } \\
\text { involved. Training } \\
\text { was provided. }\end{array}$ \\
\hline
\end{tabular}

and extensiveness of

(RS). Barriers and

facilitators to

mplementation

and use of CRS

satisfied with certain

specific technical

performance issues

of the system.

Cohen's d = N/A

(Effect size not

calculable due

to insufficient

data provided

ect. Statisticaly

conificant increase in

on-significant decrease

deptropine,

(Efect size not calculable

etwe

and expert pane

of respiratory disease.

significant, Cohen's d

diagnosis; estimated 


\begin{tabular}{|c|c|c|c|c|c|c|c|}
\hline $\begin{array}{l}\text { 18. Poels } \\
\text { et al. [52] The } \\
\text { Netherlands }\end{array}$ & $\begin{array}{l}\text { 44/-/2098 (I=15. } \\
C=15 . \text { Chest } \\
\text { physician = 14) }\end{array}$ & $\begin{array}{l}\text { Cluster-RCT } \\
\text { Duration: not } \\
\text { mentioned. }\end{array}$ & $\begin{array}{l}\text { Two interventions: GPs } \\
\text { received spirometry } \\
\text { interpretation support } \\
\text { by either a chest } \\
\text { physician (who had } \\
\text { standard spirometry } \\
\text { software) or expert } \\
\text { spirometry support } \\
\text { software. }\end{array}$ & $\begin{array}{l}\text { Usual care had } \\
\text { standard } \\
\text { spirometry } \\
\text { software } \\
\text { (i.e. no additional } \\
\text { interpretation } \\
\text { support). }\end{array}$ & $\begin{array}{l}\text { Primary: A change of } \\
\text { diagnosis after } \\
\text { spirometry } \\
\text { interpretation } \\
\text { support. Secondary: } \\
\text { referral rate, additional } \\
\text { diagnostic tests, and } \\
\text { disease management } \\
\text { changes. }\end{array}$ & $\begin{array}{l}\text { No effect. Differences in } \\
\text { proportion of changed } \\
\text { diagnoses were not } \\
\text { statistically significant. } \\
\text { There were no differences } \\
\text { in secondary outcomes. } \\
\text { (Effect was not significant, } \\
\text { Cohen's d not calculated) }\end{array}$ & Training was provided. \\
\hline $\begin{array}{l}\text { 19. Frickton } \\
\text { et al. [53], USA. }\end{array}$ & $\begin{array}{l}\text { 15/102/59,147. } \\
\text { (Patients with } \\
\text { medically } \\
\text { complex conditions } \\
\text { like xerostomia, } \\
\text { diabetes mellitus, } \\
\text { COPD, congestive } \\
\text { heart failure). }\end{array}$ & $\begin{array}{l}\text { RCT with three } \\
\text { arms (provider } \\
\text { activation, } \\
\text { patient activation } \\
\text { and control } \\
\text { group), } \\
\text { Community } \\
\text { setting. } \\
\text { Duration = } \\
2 \text { years }\end{array}$ & $\begin{array}{l}\text { Two CDS approaches. } \\
\text { In one group, dentists } \\
\text { and hygienists received } \\
\text { alerts in the EDRs } \\
\text { (electronic dental records) } \\
\text { when patients scheduled } \\
\text { for dental appointments } \\
\text { had one of the targeted } \\
\text { medical conditions. In } \\
\text { second group, in addition } \\
\text { to the above, patients } \\
\text { with upcoming dental } \\
\text { appointments who had } \\
\text { one of the targeted } \\
\text { medical conditions } \\
\text { received a notification } \\
\text { from HPDG (health } \\
\text { partners dental group) } \\
\text { before the visit, } \\
\text { encouraging them to } \\
\text { discuss it with his or } \\
\text { her dental care } \\
\text { provider at the } \\
\text { appointment. }\end{array}$ & $\begin{array}{l}\text { Patients in the } \\
\text { control group } \\
\text { received usual } \\
\text { care. Neither the } \\
\text { patients nor the } \\
\text { provider's, received } \\
\text { alerts about a patient's } \\
\text { medical status or } \\
\text { personalized care } \\
\text { guidelines. }\end{array}$ & $\begin{array}{l}\text { Primary: Total use-the } \\
\text { overall frequency with } \\
\text { which providers } \\
\text { accessed the guidelines } \\
\text { web site via the EDR } \\
\text { for any patient. Targeted } \\
\text { use- -the proportion } \\
\text { of providers who } \\
\text { accessed the care } \\
\text { guidelines in general } \\
\text { and for targeted patients } \\
\text { at the point of care. } \\
\text { Ongoing use-the } \\
\text { proportion of providers } \\
\text { who continued to access } \\
\text { the web-based guidelines } \\
\text { through-out the } \\
\text { study period. }\end{array}$ & $\begin{array}{l}\text { (+) effect. Participants } \\
\text { in the provider and } \\
\text { patient activation } \\
\text { groups increased their } \\
\text { use of the system } \\
\text { during the first six } \\
\text { months. Provider } \\
\text { activation was more } \\
\text { effective than was } \\
\text { patient activation. } \\
\text { (P< } 0.05 \text { ). However, it was } \\
\text { not sustainable, and by } \\
\text { the end of the study, } \\
\text { the rate of use had } \\
\text { returned to baseline } \\
\text { levels despite participants' } \\
\text { continued receipt of } \\
\text { electronic alerts. (Effect } \\
\text { expressed as Odds Ratio } \\
\text { for web use for provider } \\
\text { group in first six months } \\
=4.4 \text { (95\% C.I = } 1.6-12.1 \text { ) } \\
\text { and } 6-12 \text { months after im } \\
\text { plementation compared } \\
\text { to controls = } 1.7 \text { ( } 95 \% \text { C.I } \\
=0.1-2.9) \text {. For provider + } \\
\text { patient activation group, } \\
\text { effect expressed as Odds } \\
\text { Ratio for web use in first } \\
\text { six months =2.1 (95\% Cl, } \\
0-9-4.8 \text { ) and 6-12 months } \\
\text { after implementation } \\
\text { compared to controls = } \\
1.4 \text { ( } 95 \% \text { Cl } 0.5-3.5) \text {. }\end{array}$ & $\begin{array}{l}\text { Dental clinic based. } \\
\text { Study was not } \\
\text { specific to asthma/ } \\
\text { COPD patients. }\end{array}$ \\
\hline
\end{tabular}

severity of disease; referral

rate; and medication or

non-medication changes.

change of

There were no differences

in secondary outcomes.

Patients in the

(a)

Duration $=$

second group, in addition

eceived a notification

from HPDG (health

before the visit,

ppointment. 
Table 3 Quality assessment of the included randomized controlled trials

\begin{tabular}{|c|c|c|c|c|c|c|c|c|c|}
\hline Citation & $\begin{array}{l}\text { Random sequence } \\
\text { generation }\end{array}$ & $\begin{array}{l}\text { Allocation } \\
\text { concealment }\end{array}$ & $\begin{array}{l}\text { Blinding of } \\
\text { participants }\end{array}$ & $\begin{array}{l}\text { Blinding of } \\
\text { personnel }\end{array}$ & $\begin{array}{l}\text { Blinding of outcome } \\
\text { assessment }\end{array}$ & $\begin{array}{l}\text { Incomplete } \\
\text { outcome data }\end{array}$ & $\begin{array}{l}\text { Selective } \\
\text { reporting }\end{array}$ & Funding bias & Overall bias \\
\hline 1. Carroll et al. [35] & Low & Unclear & High & High & High & Low & Low & Low & High \\
\hline 2. Hashimoto et al. [36] & Low & Low & Unclear & Unclear & Low & Low & Low & Low & Low \\
\hline 3. Van der Meer et al. [37] & Low & Low & High & High & High & Low & Low & Low & Low \\
\hline 4. Van der Meer et al. [38] & Low & Low & High & High & High & Low & Low & Low & Low \\
\hline 5. Taylor et al. [39] & Unclear & Low & Low & Unclear & Low & Low & Low & Low & Low \\
\hline 6. Fiks et al. [40] & Low & Unclear & High & High & High & Low & Low & Low & High \\
\hline 7. Bell et al. [41] & Low & Unclear & High & High & High & Low & Low & Low & Moderate \\
\hline 8. Rassmusen et al. [42] & Low & High & High & High & High & High & High & High & High \\
\hline 9. Dexheimer et al. [43] & Unclear & High & High & Low & Unclear & Low & Low & Low & Moderate \\
\hline 10. Smith et al. [44] & Low & Low & Low & Low & Low & Low & Low & Low & Low \\
\hline 11. Kattan et al. [45] & Low & Low & High & High & Unclear & Low & Low & Low & Low \\
\hline 12. Tierney et al. [46] & Low & Low & Unclear & Low & High & High & Low & Low & Low \\
\hline 13. Martens et al. [47] & Low & High & Low & Unclear & Unclear & High & High & High & High \\
\hline 14. Martens et al. [48] & Low & High & Low & Unclear & Low & Low & Low & High & Unclear \\
\hline 15. Martens et al. [49] & Low & High & Low & High & Unclear & Low & Low & High & High \\
\hline 16. Kuilboer et al. [50] & Low & Low & Unclear & Low & Low & Low & Low & Unclear & Low \\
\hline 17. Poels et al. [51] & Low & Unclear & Low & Low & Low & Low & Low & Low & Low \\
\hline 18. Poels et al. [52] & Low & Unclear & High & Low & Low & Low & Low & Low & Low \\
\hline 19. Frickton et al. [53] & Low & Low & Low & High & Low & Low & Low & Low & Low \\
\hline
\end{tabular}


Table 4 Type of CCDSS and its effectiveness

Citation cCDSS CCDSS use
Type of CCDSS

Diagnostic/Drug

therapy management

only/Multifaceted

CCDSS setting

(n)

aceded

Health care process
outcomes (recommended
preventative care, clinical
study ordered,
treatment ordered)

treatment ordered)

\section{Effect of CCDSS}

Clinical outcomes
(morbidity, mortality

HRQOL, hospitalization

adverse events)

User workload and Relationship centered

Efficiency outcomes outcomes (patient

(user knowledge, satisfaction)/Economic

clinician workload, outcomes (cost and cost

effectiveness)/Use and

implementation

(health care provider

acceptance, satisfaction

use and implementation)

\begin{tabular}{|c|c|c|c|}
\hline $\begin{array}{l}\text { 1. Caroll et al. } \\
\text { [35], USA. }\end{array}$ & $\begin{array}{l}\text { Community/ } \\
\text { Integrated } \\
\text { with the EMR }\end{array}$ & Practitioners & $\begin{array}{l}\text { Diagnostic CCDSS } \\
\text { Clinician prompted } \\
\text { to make an asthma } \\
\text { diagnosis based on } \\
\text { the results of a } \\
\text { pre-screening } \\
\text { questionnaire }\end{array}$ \\
\hline
\end{tabular}

et al. [36], alone (Internet on symptoms, lung function and exhaled

Primary outcome: Asthma
No difference in

patient satisfaction

between groups

$\begin{array}{lll}\text { 2. Hashimoto } & \text { Hospital/Stand } & \text { Patients } \\ \text { et al. [36], } & \text { alone (Internet }\end{array}$
based)

$\begin{array}{lll}\text { 3. Van der } & \text { Community/ } & \text { Patients } \\ \text { Meer et al. [37], } & \text { Stand-alone } & \\ \text { Netherlands. } & \text { (Internet based) }\end{array}$

\section{Drug therapy management Primary outcome:} based CCDSS: Corticosteroid Significant decrease

treatment decision support in corticosteroid

for the patients based

NO (nitric oxide)

\section{Multifaceted CCDSS}

Weekly asthma

monitoring and advice,

online and group

education and remote

web communications

Multifaceted CCDSS:

4. Van der

Meer et al. [38],
Netherlands.

Community/

Stand-alone

(Internet based)
Patients

)

Weekly asthma

monitoring and

self-management advice. consumption in patients

with steroid dependent

asthma (+ effect)

Patients' asthma knowledge,

inhaler technique improved.

Medication changes occurred

more often. Health care

provider contacts were

fewer. (+ but modest effect)

Primary outcome:

Significantly more

children diagnosed

with asthma (+ effect)

No difference in asthma

control, quality of life,

FEV1, exacerbations,

hospitalizations

between groups.

(+ effect)

related quality of life

improved. Secondary:

Asthma control, lung

function improved,

symptom-free days

increased, exacerbations

did not differ between

groups. (+ but
modest effect)

Secondary: Significant

increase in the

corticosteroid dose in

patients with uncontrolled

asthma, but not in patients

Primary outcome:

Significant improvement

in asthma control in

patients with partly

and uncontrolled

with well or partly controlled

asthma. (+ effect)

to ACQ monitoring gradually

declined in the first month

to the seventh month and

then remained stable. No

difference in dose of

corticosteroids or LABA

or LRTA after 12 months 
Table 4 Type of CCDSS and its effectiveness (Continued)

\begin{tabular}{|c|c|c|c|c|}
\hline $\begin{array}{l}\text { 5. Taylor et al. } \\
\text { [39], Australia. }\end{array}$ & $\begin{array}{l}\text { Hospital/ } \\
\text { Integrated }\end{array}$ & $\begin{array}{l}\text { Practitioners } \\
\text { (ED doctors) }\end{array}$ & $\begin{array}{l}\text { Multifaceted CDSS: } \\
\text { The system integrated } \\
\text { asthma management } \\
\text { pathways based on } \\
\text { current guidelines into } \\
\text { clinical and discharge } \\
\text { documentation. Including } \\
\text { triage and registration, } \\
\text { clinical documentation, } \\
\text { treatment orders, order } \\
\text { entry and discharge } \\
\text { documentation. }\end{array}$ & \\
\hline $\begin{array}{l}\text { 6. Fiks et al. } \\
\text { [40], USA. }\end{array}$ & $\begin{array}{l}\text { Hospital/ } \\
\text { Integrated } \\
\text { into EHR }\end{array}$ & Practitioners & $\begin{array}{l}\text { Multifaceted CCDSS: } \\
\text { EHR based clinical } \\
\text { alerts for influenza } \\
\text { vaccine }\end{array}$ & $\begin{array}{l}\text { Primary outcome: } \\
\text { Increased Influenza } \\
\text { vaccination rates. } \\
\text { (+ effect, but } \\
\text { not significant) }\end{array}$ \\
\hline $\begin{array}{l}\text { 7. Bell et al. } \\
\text { [41], USA. }\end{array}$ & $\begin{array}{l}\text { Hospital/ } \\
\text { Integrated } \\
\text { into EHR }\end{array}$ & Practitioners & $\begin{array}{l}\text { Multifaceted CCDSS: } \\
\text { EHR based CDS alerts } \\
\text { and reminders based } \\
\text { on pediatric asthma } \\
\text { management tool } \\
\text { (PACT) which captured } \\
\text { asthma symptom } \\
\text { frequency, asthma } \\
\text { severity, facilitated } \\
\text { ordering of controller } \\
\text { medications, spirometry } \\
\text { and ACP (asthma } \\
\text { action plan) }\end{array}$ & $\begin{array}{l}\text { Primary outcome: } \\
\text { Increase in the } \\
\text { number of controller } \\
\text { medication prescriptions, } \\
\text { and up-to-date asthma } \\
\text { action plan (ACP). } \\
\text { (+ effect, but not } \\
\text { significant). } \\
\text { Increase in the use of } \\
\text { spirometry in the } \\
\text { intervention group } \\
\text { (+ effect, but } \\
\text { not significant) }\end{array}$ \\
\hline $\begin{array}{l}\text { 8. Rasmussen } \\
\text { et al. [42], } \\
\text { Denmark }\end{array}$ & $\begin{array}{l}\text { Stand-alone } \\
\text { (internet based) }\end{array}$ & Patients & $\begin{array}{l}\text { Multifaceted CCDSS: } \\
\text { Internet based asthma } \\
\text { monitoring tool consisting } \\
\text { of an asthma diary, action } \\
\text { plan and a decision } \\
\text { support for the physician }\end{array}$ & $\begin{array}{l}\text { Significantly more } \\
\text { patients using inhaled } \\
\text { corticosteroids in the } \\
\text { internet and specialist } \\
\text { group (+ effect) }\end{array}$ \\
\hline $\begin{array}{l}\text { 9. Dexheimer } \\
\text { et al. [43], USA. }\end{array}$ & $\begin{array}{l}\text { Hospital/ } \\
\text { Integrated }\end{array}$ & $\begin{array}{l}\text { Practitioners } \\
\text { (ED physician) }\end{array}$ & $\begin{array}{l}\text { Multifaceted CCDSS: } \\
\text { Computerized detection } \\
\text { system screened and } \\
\text { identified patients with } \\
\text { asthma exacerbation } \\
\text { and a guideline based } \\
\text { management protocol }\end{array}$ & $\begin{array}{l}\text { Secondary outcome: } \\
\text { No difference in asthma } \\
\text { education charted, } \\
\text { medication prescribed, } \\
\text { follow-up appointment } \\
\text { scheduled (No effect) }\end{array}$ \\
\hline $\begin{array}{l}\text { 10. Smith } \\
\text { et al. [44], UK. }\end{array}$ & $\begin{array}{l}\text { Community/ } \\
\text { Integrated } \\
\text { (with the EHR) }\end{array}$ & Practitioners & $\begin{array}{l}\text { Multifaceted CCDSS: } \\
\text { EHR based alerts to flag } \\
\text { the at-risk status of } \\
\text { patients to improve } \\
\text { patient access and } \\
\text { opportunistic management }\end{array}$ & $\begin{array}{l}\text { Relative increase in } \\
\text { LABA usage and } \\
\text { decrease in } \\
\text { nebulized } \\
\text { B-agonists } \\
\text { (+ effect) }\end{array}$ \\
\hline
\end{tabular}

Primary outcome:

Significantly highe

rate of asthma

documentation.

Secondary outcome:

No significant

difference in

consultation time.

(+ effect)

\section{Primary outcome:}

Significant improvement

in asthma symptoms,

$A Q L Q$, lung function,

but no change in airway

responsiveness (+ effect)

No difference in

admission rate

ED length of

stay (no effect)

Primary outcome:

No significant difference

in the number of people

experiencing exacerbations.

Relative reduction in people

experiencing hospitalizations,

\section{Primary outcome:}

No significant

difference in the

time taken to make a

ED disposition

decision (no effect)
Cost -effectiveness

outcome: Adjusted mean

health care (NHS) cost

lower among intervention

practices compared to

control practices (+ effect) 
12. Tierney et al. Hospital/

[46], USA. Integrated

13. Martens et al. Community/ [47], Netherlands. Integrated

14. Martens et al. Community/ [48], Netherlands Integrated

Practitioners

15. Martens et al. Community/ [49], Netherlands. Integrated

Physicians

Practitioners

GPs)

Practitioners (GPs)

\section{Drug therapy \\ based CCDSS:}

Computer generated

letter recommending

change in controller

medications based

on NAEPP guidelines

\section{Practitioners}

and pharmacists) focusing on immunization,

prescription and

smoking advice

\section{Drug therapy}

based CCDSS: Guidelin

based reminders when

prescribing antibiotics,

cholesterol prescriptions

Drug therapy

management based

CCDSS: Guideline based

reminders when

prescribing antibiotics,

asthma/COPD and

cholesterol prescriptions
Primary outcome:

Significant increase

in scheduled visits

up of asthma

Primary outcome: No

difference in the

adherence to

guideline-based care

suggestions measured

as the number of tests

and treatment ordered

(No effect)

\section{Primary outcome:}

Reductions in the

number of prescriptions

according to the

guidelines (+ effect,

but not significant)

Primary outcome: Clinically

meaningful results seen in

not prescribing certain

drugs in the intervention

group (+ effect, but

not significant) accident and

emergency attendances,

out-of-hour

contacts and other

health care use.

(+ effect, but

not significant)

Significant decrease

in ED visits. No

difference in maximum

number of symptom

days and school days

number of days with

activity limitation.

No effect on quality

of life, clinical symptoms,

medication adherence

and compliance, ED

visits or hospitalizations

(No effect)

the group receiving

only physician intervention.

Physicians attitude towards guidelines was mixed

Providers perceived the

CRS as stable and use

friendly (+ effect,

but not significant)
Intervention-reduced

the health services and

was cost-effective.

\begin{tabular}{|c|c|}
\hline $\begin{array}{l}\text { Significant learning } \\
\text { curve was found } \\
\text { (shows improvement } \\
\text { in user knowledge) } \\
\text { (+ effect) }\end{array}$ & $\begin{array}{l}\text { Primary outcome: Provider } \\
\text { use: Only 9\% drop-out rate } \\
\text { (because of technical } \\
\text { problems requiring } \\
\text { multiple updates) } \\
\text { (+but not significant } \\
\text { effect) Provider } \\
\text { satisfaction: Positive } \\
\text { attitude to the content } \\
\text { of the reminders and } \\
\text { satisfied with the } \\
\text { user friendliness }\end{array}$ \\
\hline
\end{tabular}

based CCDSS: Guideline

based reminders when

prescribing antibiotics,

asthma/COPD and

cholesterol prescriptions 
Table 4 Type of CCDSS and its effectiveness (Continued)

\begin{tabular}{|c|c|c|c|c|c|c|}
\hline $\begin{array}{l}\text { 16. Kuilboer et al. } \\
\text { [50], Netherlands. }\end{array}$ & $\begin{array}{l}\text { Community/ } \\
\text { Integrated }\end{array}$ & $\begin{array}{l}\text { Practitioners } \\
\text { (General } \\
\text { practitioners) }\end{array}$ & $\begin{array}{l}\text { Multifaceted CCDSS: } \\
\text { Asthma critic evaluates } \\
\text { whether the patient has } \\
\text { asthma or COPD, reviews } \\
\text { the physicians treatment, } \\
\text { and generates feedback }\end{array}$ & $\begin{array}{l}\text { Primary outcome: Significant } \\
\text { increase in the average number } \\
\text { of contacts. Significant } \\
\text { decrease in the average } \\
\text { number of cromogylate } \\
\text { prescriptions. No statistically } \\
\text { significant change in the } \\
\text { antihistamines, deptropine, and } \\
\text { oral bronchodilator } \\
\text { prescriptions per asthma/COPD } \\
\text { patient per practice (+ effect) }\end{array}$ & $\begin{array}{l}\text { Significant increase in FEV1 } \\
\text { (forced expiratory volume), } \\
\text { and peak-flow measurements } \\
\text { per asthma/COPD patient } \\
\text { per practice (+ effect) }\end{array}$ & \\
\hline $\begin{array}{l}\text { 17. Poels et al. } \\
\text { [51], Netherlands. }\end{array}$ & $\begin{array}{l}\text { Community/ } \\
\text { Stand-alone } \\
\text { (spirometry } \\
\text { expert system) }\end{array}$ & $\begin{array}{l}\text { Practitioners } \\
\text { (GPs) }\end{array}$ & $\begin{array}{l}\text { Multifaceted CCDSS: } \\
\text { Presentation of data for } \\
\text { diagnosis and } \\
\text { management of } \\
\text { chronic airway disease }\end{array}$ & $\begin{array}{l}\text { Primary outcome: No } \\
\text { difference in between the } \\
\text { two groups (Spirometry } \\
\text { expert system and sham } \\
\text { information) in the diagnosis } \\
\text { of COPD, asthma and } \\
\text { absence of respiratory } \\
\text { disease or in medication } \\
\text { changes. Secondary: Slightly } \\
\text { more additional diagnostic } \\
\text { tests in the expert group } \\
\text { (No effect) }\end{array}$ & & \\
\hline $\begin{array}{l}\text { 18. Poels et al. } \\
\text { [52], Netherlands. }\end{array}$ & $\begin{array}{l}\text { Community/ } \\
\text { Integrated? } \\
\text { (not clear) }\end{array}$ & $\begin{array}{l}\text { Practitioners } \\
\text { (GPs) }\end{array}$ & $\begin{array}{l}\text { Multifaceted CCDSS: } \\
\text { Spirometry expert } \\
\text { support for change } \\
\text { in diagnosis and } \\
\text { management }\end{array}$ & $\begin{array}{l}\text { Primary outcome: No } \\
\text { differences in the proportion } \\
\text { of changed diagnosis } \\
\text { between the three groups } \\
\text { (spirometry expert system, } \\
\text { chest physician and usual } \\
\text { care). Also no difference } \\
\text { between the groups in } \\
\text { referral rate, additional } \\
\text { diagnostic tests and } \\
\text { medication changes } \\
\text { (No effect) }\end{array}$ & & \\
\hline $\begin{array}{l}\text { 19. Frickton et al. } \\
\text { [53], USA. }\end{array}$ & $\begin{array}{l}\text { Community/ } \\
\text { Integrated } \\
\text { (with the EDR) }\end{array}$ & $\begin{array}{l}\text { Practitioners } \\
\text { (Dentists) and } \\
\text { patients }\end{array}$ & $\begin{array}{l}\text { Multifaceted CCDSS: } \\
\text { EDR (Electronic dental } \\
\text { record) based alerts } \\
\text { notifying the dentists } \\
\text { of the presence of a } \\
\text { medically complex } \\
\text { condition in a } \\
\text { patient with a link } \\
\text { to modify dental } \\
\text { care appropriately }\end{array}$ & & & $\begin{array}{l}\text { Primary outcome: } \\
\text { Significant increase in } \\
\text { the frequency of dentists } \\
\text { accessing guidelines } \\
\text { (number of website hits } \\
\text { and number of providers } \\
\text { using the guideline). Only } \\
\text { number of hits sustained } \\
\text { after } 6 \text { months. After } 9 \\
\text { months provider use } \\
\text { returned to baseline levels } \\
\text { (+ effect) }\end{array}$ \\
\hline
\end{tabular}

Primary outcome:

the frequency of dentists accessing guidelines

umber of website hits months provider use 


\section{Effectiveness of CCDSS}

Using classifications published in previous reviews pertaining to CCDSS [54], we assessed CCDSS effectiveness based on the following key outcomes:

(1)Clinical outcomes: Morbidity, health related quality of life, hospitalizations and mortality. [e.g. asthma symptoms (measured using symptom diary), asthma control (Asthma control Questionnaire-ACQ), lung function (Piko-1 device, peak flow meter), healthrelated quality of life (measured using HRQOL) and adverse events (leading to unscheduled doctors visit or hospitalization)];

(2) Healthcare process measures: Recommended preventive care services ordered or completed (e.g. influenza vaccination), recommended clinical study ordered or completed (including spirometry), recommended treatment ordered or completed (including rescue medication prescriptions and antibiotic prescriptions)];

(3) User workload and efficiency outcomes: Effect on user knowledge, number of patients seen per unit time, clinician workload, and efficiency;

(4) Relationship-centered outcomes: Patient satisfaction surveys;

(5)Economic outcomes: Cost and cost effectiveness of the CCDSS used; and

(6) Use and Implementation outcomes: Health care provider acceptance, health care provider satisfaction, and health care provider use and implementation.

A CCDSS was considered effective if it produced a statistically significant $(\mathrm{p}<0.05)$ improvement in the primary outcome or improvement in $\geq 50 \%$ of multiple relevant pre-specified outcomes. If the authors did not designate a primary outcome, we considered the outcome used to calculate the trial's sample size to be primary. Studies that included multiple intervention arms were considered effective if any of the CCDSS based treatment arms was evaluated as effective.

Although we had intended to conduct meta-analyses, this was abandoned owing to the marked heterogeneity in participants, clinical settings, interventions, and the outcomes measured in the included studies. However, effect sizes (Cohen's d value) of the significant primary outcomes were calculated wherever possible.

\section{Results}

The PRISMA guidelines for conducting/reporting systematic reviews were consulted and a completed checklist is attached as Additional file 1. We screened 1042 abstracts, identified 173 full-text potentially relevant articles and included 19 articles representing 16 RCTs in the review (Figure 1).
Studies were predominantly conducted in the Netherlands $(n=9)$ and the USA $(n=7)$ with one study conducted in each of the following countries: Australia, United Kingdom and Denmark.

Eleven studies evaluated asthma care [35-45], 5 studies involved patients with asthma and COPD [46-50], and 3 studies focused on people with medically complex conditions including COPD [51-53]. There were no studies conducted exclusively on people with COPD (Table 2).

\section{Study quality}

A summary of the study quality of the included studies is reported in Table 3. Of the 19 trials, 10 studies had a low risk of bias [36-39,44-46,51-53]. Eleven studies described an appropriate method of sequence generation [35-38,44-46,50-53], 9 studies reported adequate concealment of allocation [36-39,42,44,46,50,53], and 13 studies showed either no differences in baseline characteristics between study groups or performed appropriate adjustments [35-37,39,40,42-46,50,51,53]. Eleven studies used objective outcomes or blinding of outcome assessments $[36,39,40,43-45,48,50-53]$, and 11 studies achieved a $\geq 90 \%$ follow-up rate for their unit of analysis [35-39,44-46,48-50].

\section{CCDSS and study characteristics}

Table 2 describes the CCDSS design and implementation characteristics. The majority of interventions (68\%) (13/ 19) were embedded in an existing electronic medical record (EMR) or with the computerized physician order entry (CPOE) systems [35,39-41,43,44,46-52]. Thirty-one percent (6 studies) had a stand-alone system, of which four were internet based [36-38,42] and in the other 2 studies CCDSS intervention were administered to practitioners by the study researchers $[45,52]$. Five of the six studies with the stand-alone CCDS system showed positive impact. Sixty-three percent (12 studies) automatically prepopulated the EMR data [35-41,43,44,46,50,53], 26\% (5 studies) relied on practitioners to manually enter the data [42,47-49,52], 16\% (3 studies) relied on research staff $[44,45,51]$ and $21 \%$ (4 studies) relied on patients as well for data inputs [36-38,42]. Forty-seven percent (9 studies) compared a computerized clinical decision support system directly with usual care [35-38,40,43,44,50,52].

Advice at the point-of-care was provided in 14 trials [35,39-41,43,44,46-53] and via the internet in 4 trials [36-38,42]. Advice in the form of a computer-generated letter recommending changes to the treatment was provided to the practitioners in one study [45]. Advice was provided only to the physicians in 68\% (13 trials) [35,39-41,43, 44,46-52], while only one trial involved provision of advice to other healthcare practitioners (pharmacists) in addition to physicians [46]. In 26\% (5 studies) patients were directly advised in addition to practitioners [36-38,42,53]. Thirteen studies provided explicit training in use of the CCDSS to 


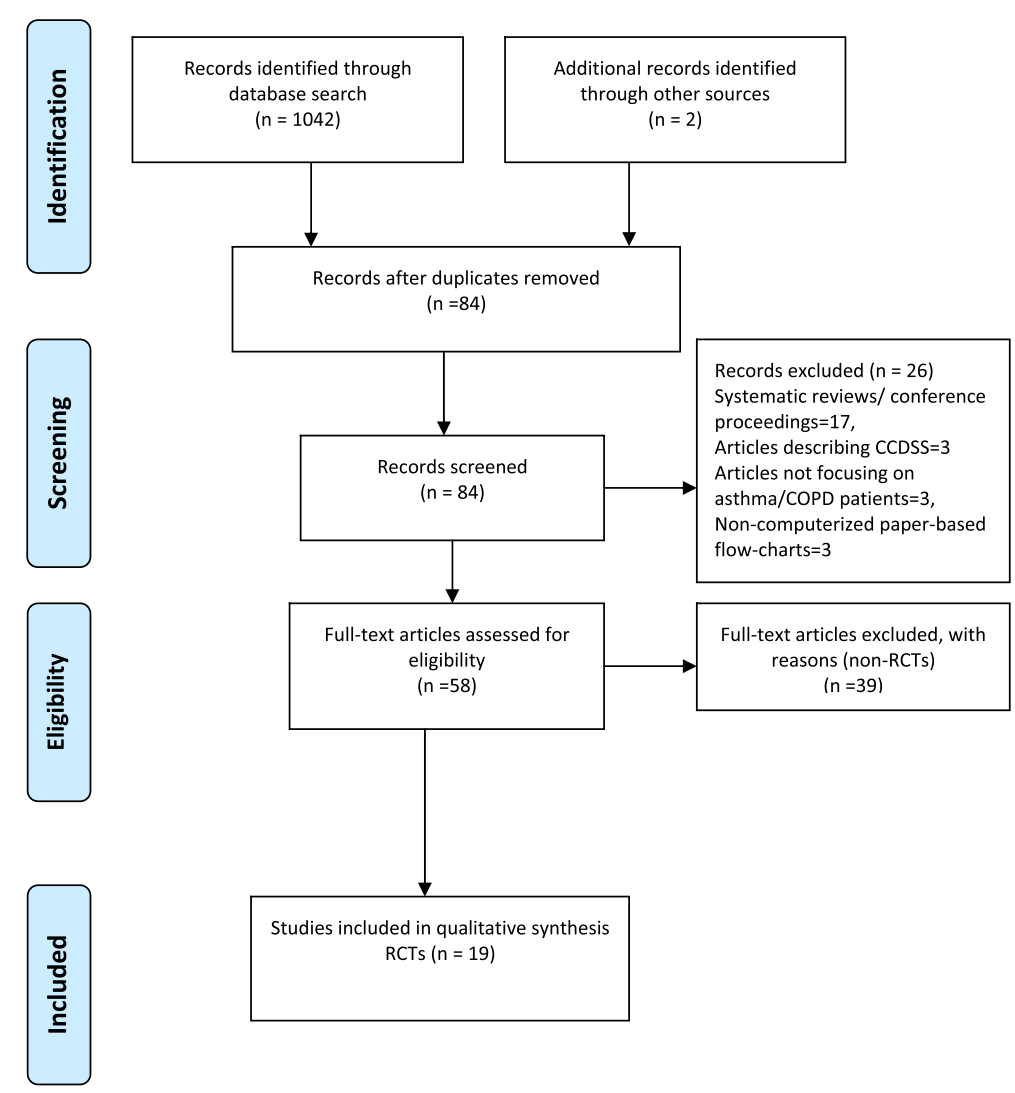

Figure 1 PRISMA flow diagram of the included and excluded studies [55].

healthcare practitioners [39,41-52], while patients were trained to use the internet based CCDSS in 3 trials [36-38]. The CCDSS user interface characteristics were described in only $42 \%$ (8) of the trials [35,38,39,43,48-50,53].

Studies included a highly varied number of healthcare practitioners, patients and health services.

Since CCDSS is primarily focused on altering provider behavior, the unit of randomization in most CCDSS studies was the provider. Thirty-seven percent (7) of the studies reviewed were randomized at the provider, practice or community level [39,45,46,50-53], while $31 \%$ (6) used cluster randomization either between clinics or groups of providers that worked closely together [40,41,44,47-49]. Thirty-one percent (6 studies) were randomized at the patient level [35-38,42,43].

In all studies that included patient level randomization there was potential for contamination given a single provider could care for both intervention and control arm patients. The principal summary measures used to compare effects between intervention and control groups varied and included: proportions [35,39,41,45]; difference in medians [36,38,43,50]; difference in means [46,48]; relative risk [37] and odds ratios [40,42,44,51-53].

Three trials did not clearly report their source of funding $[41,42,53]$. Of the remaining, 9 trials were publicly funded [36,37,41,43,45,46,51-53], 5 trials were conducted with only private funds [40,44,47-49], 1 trial was conducted with a combination of private and public funding [42], while another trial did not receive any funding [35]. Five trials declared that at least one author was involved in the development of the CCDS system [37,38,47-49], while the remaining trials did not indicate at all if the authors were independent of development.

\section{Type of CCDSS interventions}

The included studies utilized CCDSS for a variety of purposes, and were categorized in to three main categories, such as those focusing on screening/diagnosis, drug therapy management, and multifaceted interventions which involved various aspects of disease management along with self-management advice (Table 4).

There was only one study, conducted by Caroll et al. that used the CCDSS (Child Health Improvement through Computer Automation-CHICA system) for the purpose of diagnosing pediatric asthma [35]. Five studies (26\%) used the CCDSS for drug therapy management [36,45,47-49], and thirteen used a multi-faceted form of CCDSS [37-44,46,50-53].

The studies evaluating the CCDSS focusing on drug therapy management included the study by Hashimoto 
et al. which utilized an Internet based treatment decision support system to guide people with severe asthma in tapering the dose of oral corticosteroids depending on their asthma control [36]. The study by Kattan et al. involved provision of a computer-generated letters to the treating physician summarizing the appropriate treatment recommendations based on the child's asthma symptoms, health service and medication use [45]. The three studies conducted by Martens et al. also involved a CCDSS in the form of reactive computer reminders (CRS) to improve drug prescribing in general practice [47-49].

The remaining 13 studies (68\%) evaluated multifaceted forms of CCDSS [37-44,46,50-53]. These CCDSSs ranged from simple activation of electronic alerts to identify people at risk of an asthma exacerbation [44], or prompts to alert the physician to modify treatment in people with medically complex conditions at the point of care [53], to more complex forms of CCDSS interventions involving a series of care suggestions on drug therapy and disease management [46]. Internet-based multifaceted CCDSS interventions were evaluated in three trials which focused on the self-management of asthma $[37,38,42]$. These studies utilized online self-management programs which involved weekly online asthma control monitoring and feedback in the form of treatment advice by a specialized asthma nurse [37,38], or by the patients' physician [42]. Another type of multifaceted CCDS interventions evaluated in two other studies were in the form of EHR-based clinical alerts either to improve influenza vaccination in children with asthma [40], or to improve overall asthma care in these children [41]. The multifaceted CCDSS evaluated by Kuilboer et al. was a critiquing system integrated with the general practitioners' electronic medical records which reviewed physicians' treatment decisions and generated feedback [50]. Another two studies evaluated the impact of an expert spirometry system on the physician's decision making during asthma diagnosis [51] and during management [52]. The remaining two trials also tested the effects of another multifaceted CCDSS on the clinician's performance in the form of an electronic interface system to manage asthma patients in ED [39] and in the form of an automated asthma detection system used to identify and manage people at risk of asthma exacerbation in the emergency department [43].

\section{CCDSS effectiveness}

There was marked variability in the outcomes reported. Therefore we assessed the effectiveness of the CCDSS on the primary outcomes measured. In majority of the trials reviewed, the primary outcomes assessed were health care process measures, clinical outcomes, user work load and efficiency, and use and implementation outcomes. Relationship-centered outcomes and economic outcomes were measured by few trials, but only as secondary outcomes. Fourteen trials (74\%) showed positive effect from the use of CCDSS on the primary outcome measured, of these $9 / 19(47.3 \%)$ showed a significantly positive effect $[35,36,38,39,41,42,45,50,53]$.

\section{Clinical outcomes}

The different clinical outcomes reported in the studies included asthma symptoms [42], asthma/COPD symptoms [46] asthma control (ACQ) [36-38], Health related Quality of life $[36,37,42,46]$, frequency of health care utilizations including hospitalizations [36,44], admission rate and ED length of stay [43], frequency of exacerbations $[36,37,44]$, lung function (FEV1) in asthma patients $[36,37,42]$, exhaled nitric oxide [36], symptom free days [37], airway hyper responsiveness [42], number of ED visits [45,46] number of school days missed [45], medication adherence [46], FEV1 and peak flow measurements in asthma/COPD patients [50].

Five of the nineteen trials assessed clinical outcomes as the primary outcome measure $[35,37,38,42,44]$, of which three showed clinically significant improvements $[35,38,42]$, one showed a positive but modest improvement in the asthma related quality of life [37] and another one did not show any effect on the number of people experiencing an exacerbation from the use of EHR embedded asthma risk alerts [44].

Significant improvement was found in the rate of diagnosis of asthma in children by implementation of a parent survey linked to physician prompts using computer decision support system called the CHICA system [35]. Significant improvement was also found in asthma control measured weekly using the asthma control questionnaire (ACQ) [38], in asthma symptoms using an electronic diary to record symptoms daily and in the asthma quality of life measured using asthma quality of life questionnaire (AQLQ) [42]. The effect sizes (Cohen's d) calculated for the studies showing significant improvement in the primary clinical outcomes ranged from 0.24 to 0.94 , with three studies showing a reasonably large effect size $[37,38,42]$.

\section{Health care process outcomes}

The different health care process measures that were assessed in the reviewed trials included change in the consumption of oral corticosteroid [36], change in the dose of inhaled corticosteroid [38,42], change in patients' asthma knowledge [37], change in inhaler technique [37], change in medication adherence [37], medication changes $[37,38,44]$, adherence to the use of ACQ [38], rate of vaccination [40], number of corticosteroid prescription ordered [41], provision of asthma action plan [41], spirometry ordered [41], rate of asthma documentation by ED doctors [43], scheduled physician visits leading to change in medication dose [45,50], physicians adherence to guidelines [46], 
change in the number of prescriptions $[47,48,50]$, change in the diagnostic ability of the general practitioner [51,52], diagnostic tests ordered [51,52] and the rate of referral [52].

Ten trials assessed health care process measures as the primary outcome [36,40,41,45-48,50-52], of which four showed significant improvement in these outcomes. Significant improvement was seen in process outcomes like cumulative sparing of prednisone dose adjusted weekly according to the internet based CDSS [36], percentage of children given at least one prescription of corticosteroid [41], percentage of visits to the physician leading to medication step up of asthma medication [45] and in the number of contacts with the patients' physician [50]. The effect size calculated for the two studies $[36,45]$ with significantly positive improvement was however poor. Three trials showed a positive but modest effect of which one showed a modest improvement in the rate of influenza vaccination by the use of EHR alerts [40]. The other 2 trials showed a modest improvement in the drug prescribing behavior of GPs from the use of the CRS reminders $[47,48]$. The remaining 3 studies did not show any effect from the use of CCDSS on the primary health care process outcome assessed.

\section{User workload and efficiency outcomes}

Workload and efficiency outcomes assessed in the trials included asthma documentation by emergency department (ED) doctors [39], consultation time [39], time for disposition decision in the ED [43], and user knowledge [49]. These outcomes were assessed as the primary outcome by only two trials $[39,43]$, of which one trial showed significant improvement in the rate of asthma documentation by the ED doctors in the management of acute asthma [39]. The size of the effect calculated for this trial was relatively large (Cohen's $d=0.78$ ). However the other trial did not show any effect from the use of CCDSS on the time taken by the ED physicians to make a disposition decision [43].

\section{Use and implementation outcomes}

The outcomes assessed under this category were physicians attitude to guidelines [46], user friendliness [48,49], provider satisfaction [49], and the rate of accessing guidelines [53]. Two trials assessed these outcomes as the primary outcome, of which one showed a significant improvement in the rate of use of guidelines by dentists in the management of people with chronic diseases including COPD [53]. The study showed that the use of CCDSS increased the number of times the dentists accessed the guidelines. The other trial also showed a positive but modest effect in the use of CRS (reactive computer reminders) by general practitioners, not to prescribe certain drugs [49].

\section{Other outcomes}

Outcomes such as patient satisfaction with CCDSS use was measured as a secondary outcome by two trials and found no difference in patient satisfaction between the intervention and the control group patients [36,46]. Measures such as health care provider satisfaction were also assessed as secondary outcomes. Of the three studies that measured these outcomes $[46,47,49]$, two found that the provider perceived the CCDSS as user friendly. Only one trial measured cost of the intervention and found that the patients in the group receiving the CCDSS intervention had significantly elevated total health care charges [46]. Two other trials measured the cost-effectiveness of the CCDSS used and both found that its use was more cost effective than usual asthma care $[44,45]$.

\section{Discussion}

This is the first comprehensive review of CCDSS in the care of patients with chronic respiratory diseases, asthma and COPD. The review focused only on studies conducted in primary care as the bulk of the management of these chronic diseases happens in primary care. The review found that the use of CCDSS can have a positive impact on the diagnosis and management of asthma and COPD in primary care. Overall $74 \%$ of the studies reviewed showed improvement in the primary outcomes. Although there is literature available on the use of CCDSS in patients with asthma, there is very little literature on its use in the management of people with COPD.

The review also found that $83 \%(5 / 6)$ of the studies that utilized CCDSS with a stand-alone design showed positive outcomes as compared to studies testing CCDSS which were integrated with the EHR or the EMR systems (38\%) (5/13). This indicates that systems presenting advice within electronic health records or order entry systems were much less likely to improve care or outcomes than stand-alone programs. It has been found that when integration of alerts within an institution's electronic health records becomes possible and more alerts are added, practitioners might become overwhelmed and begin to ignore the prompts. This "alert fatigue" phenomenon [56] could be responsible for limiting behavior change. Studies estimate that as many as $96 \%$ of alerts are over ridden [57-59] and suggest that the threshold for alerting is too low (that is, alerts are sensitive but not specific). Systems requiring the practitioner to give a reason for overriding advice were more likely to succeed than systems missing this feature [60].

Four of the five studies evaluating CCDSS with a stand-alone design, were Internet-based interventions targeting both physicians and patients. All the four studies showed that CCDSSs which targeted the patients as well as the physicians were effective in improving outcomes. The findings are consistent with other previous 
reviews of CCDSS for chronic disease management in primary care [33,61]. A key feature of these interventions was the active incorporation of a patient self-management component for use outside of the clinical encounter. The CCDSS interventions included in the studies involved regular monitoring and feed-back along with patient education and follow-up. These results confirm the value of collaborative care in chronic respiratory disease management.

Also CCDSS interventions consisting of multiple components such as reminders and education were associated with greater improvement in outcomes than single-target interventions with fewer components. This is also reflected in other reviews evaluating the effectiveness of such multicomponent CCDSSs engaging patients in the management of other chronic conditions like diabetes [33] and osteoporosis [62]. Given the advent of personal health records, patient portals, and mobile applications aimed at better engaging patients, the findings suggest that there is a need to consider multiple components and targets in the development of any future interventions.

Of the outcomes measured many of the included studies (53\%) often focused on measuring the effectiveness of CCDSSs on the health care process outcomes and the evidence demonstrating the effects of CCDSSs on patient outcomes, user workload and efficiency and economic outcomes remains surprisingly low. This is comparable to other recent CCDSS reviews which also report on the paucity of well-designed studies evaluating the effects of CCDSS on patient related outcomes [32,63]. This may have occurred owing to under powering, since most of the studies may not have had large enough sample sizes to detect such outcomes. Similarly many of these studies were not conducted over longer time frames. Both the sampling and time issues were possibly due to the relative difficulty of implementing randomized, controlled trials in real clinical settings [54]. Since clinical decision support has a primary function aimed at providing information to the provider at the point of decision making and intervention, outcomes which measure process or provider behavior are often used as a proxy for patient outcomes [61]. Although analysis of process outcomes has a merit as an interim platform to justify the continuing role of CCDSS in clinical care, more research is needed on evaluating the effectiveness of CCDSS on patient outcomes in order to adequately understand the usefulness of CCDSS in clinical setting. Nevertheless, $60 \%$ of the 5 studies measuring clinical outcomes showed significantly positive impact on these outcomes as compared to $40 \%$ of the 10 studies showing significant improvement in health care process outcomes. This implies that the implementation of CCDSS for asthma/COPD care seems promising in improving clinical outcomes. The most commonly reported clinical outcomes were asthma control and asthma quality of life.
CCDSSs may represent a cost-effective way of improving chronic respiratory disease outcomes in primary care. However, the review found that the economic effects of these systems could not be readily assessed based on the available data. The costs of design, local implementation, ongoing maintenance, and user support can be high, and may be further elevated by the unique nature of chronic respiratory care. This warrants cost-effectiveness analyses, but only two trials reported such data and little cost data of any kind was available across studies. Almost all of the studies discussed the need for more research utilizing cost-effectiveness outcomes to better assess the long term effectiveness of CCDSS.

The review also found that there were no studies that demonstrated a negative finding (patient harm or deterioration related to the intervention). This could be because the studies did not actively collect any data on harm assessment of the CCDSS used. Prospective data on the possible harms of CCDSSs are needed to facilitate informed adoption decisions. Based on the available evidence it is hard to draw conclusions about the potential negative effect of implementing decision-support tools, which is necessary to truly fulfil the goal of evaluating these interventions and to better address implementation challenges [64].

\section{Strengths and limitations}

The review has several important strengths. This is the first review evaluating the role of CCDSS in the management of chronic respiratory diseases, asthma and COPD in primary care. We particularly excluded studies regarding in-patient hospital based CCDSSs as we intended to focus its effectiveness in primary and community health care, given that only a small proportion of people with, asthma for example, are managed in the hospital setting. The search strategy of our study was extensive and thorough, and covered a large number (eight) of relevant databases to identify potentially relevant studies. The other strength is we based our review on the strongest studies available, RCTs. Also to reduce the risk of selection bias and incorrect categorization all the included articles were analyzed and critically examined by three reviewers independently.

There are a number of key limitations to this review. We excluded studies regarding in-patient hospital based CCDSSs as we intended to focus its effectiveness in primary and community health care. We included only English language studies conducted in the last 10 years as we wanted to document the recent advances in this area. Our analyses were limited to published reports of randomized controlled trials, so the possibility of publication bias or selective reporting must be acknowledged. The CCDSSs were grouped into categories based on clinical applications rather than on other aspects of 
CCDSS design. We were unable to conduct meta-analysis, given the substantial heterogeneity in the type of CCDSSs and the outcomes evaluated, however we calculated the effect sizes of the primary outcomes for easier comparison of the study effects. Finally, we summarized only randomized controlled trials which might have resulted in less information about issues related to CCDSS implementation, effect on workflow, and factors affecting usability.

\section{Conclusion}

In summary, the review demonstrates that CCDSS can improve chronic disease management processes and clinical outcomes in patients with asthma and COPD, but data showing its effect on use and implementation and economic outcomes were sparse. The review also found that although there are a growing number of RCTs that assessed a wide variety of CCDSSs designed to improve asthma management in primary care, there is very scant evidence of its use in the care of patients with COPD.

The mechanisms behind systems' success or failure remain understudied, but non-integrated, multifaceted CCDSS providing advice to both practitioners and patients, and those requiring the practitioners to give explanations for over-riding advice might independently improve success.

Future trials with clear descriptions of system design, local context, implementation strategy, costs, adverse outcomes, user satisfaction, and impact on user workflow will better inform CCDSS development and decisions about local implementation.

\section{Additional file}

\section{Additional file 1: PRISMA checklist.}

\section{Abbreviations}

COPD: Chronic Obstructive Pulmonary Disease; CCDSS: Computerized clinical decision support systems; EMR: Electronic medical records; EHR: Electronic health records; CRS: Computer reminder system; CPOE: Computerized physician order entry; EDR: Electronic dental records.

\section{Competing interests}

The authors declare that they have no competing interests.

\section{Authors' contributions}

MF was responsible for the study conception and design and undertook the searches, selection and quality assessment of the studies, extraction and interpretation of data. PNP duplicated the searches, conducted selection and quality assessment of the studies. MF wrote the initial draft of the paper. DP contributed to the interpretation of the findings. DP, CA and BS critically revised the manuscript. All authors contributed to and have approved the final text.

\section{Funding}

This research received no specific grant from any funding agency in the public, commercial or not-for-profit sectors.

\section{Author details}

${ }^{1}$ Sydney Medical School, University of Sydney, Sydney, New South Wales, Australia. ${ }^{2}$ Woolcock Institute of Medical Research, Sydney Medical School,
University of Sydney, Sydney, New South Wales, Australia. ${ }^{3}$ The George Institute for Global Health, Sydney Medical School, University of Sydney, Sydney, New South Wales, Australia. ${ }^{4}$ Faculty of Pharmacy, University of Sydney, Sydney, New South Wales, Australia.

Received: 11 June 2014 Accepted: 19 November 2014 Published: 2 December 2014

\section{References}

1. World Health Organization: Global surveillance, prevention and control of chronic respiratory diseases: a comprehensive approach. 2007. http://www.who.int/gard/publications/chronic_respiratory_diseases.pdf.

2. Bahadori K, Doyle-Waters MM, Marra C, Lynd L, Alasaly K, Swiston J, FitzGerald J: Economic burden of asthma: a systematic review. BMC Pulm Med 2009, 19(9):24.

3. Australian Centre for Asthma Monitoring: Asthma in Australia 2011: with a focus chapter on chronic obstructive pulmonary disease. Asthma series no. 4. Cat. no. ACM 22. In Canberra: AlHW; 2011. http://www.aihw.gov.au/ publication-detail/?id=10737420159.

4. Lozano R, Naghavi M, Foreman K, Lim S, Shibuya K, Aboyans V, Abraham J, Adair T, Aggarwal R, Ahn SY, Alvarado M, Anderson HR, Anderson LM, Andrews KG, Atkinson C, Baddour LM, Barker-Collo S, Bartels DH, Bell ML, Benjamin EJ, Bennett D, Bhalla K, Bikbov B, Bin Abdulhak A, Birbeck G, Blyth F, Bolliger I, Boufous S, Bucello C, Burch M, et al: Global and regional mortality from 235 causes of death for 20 age groups in 1990 and 2010: a systematic analysis for the Global Burden of Disease Study 2010. Lancet 2012, 380:2095-2128.

5. Lalloo UG, Walters RD, Adachi M, de Guia T, Emelyanov A, Fritscher CC Hong J, Jimenez C, King GG, Lin J, Loaiza A, Nadeau G, Neffen H, Sekerel BE, Yorgancıoğlu A, Zar HJ: Asthma programmes in diverse regions of the world: challenges, successes and lessons learnt. Int J Tuberc Lung Dis 2011 , 15:1574-1587.

6. Adams RJ, Fuhlbrigge A, Guilbert T, Lozano P, Martinez F: Inadequate use of asthma medication in the United States: results of the asthma in America national population survey. J Allergy Clin Immunol 2002, 110(1):58-64.

7. Finkelstein JA, Lozano P, Farber HJ, Miroshnik I, Lieu TA: Underuse of controller medications among Medicaid-insured children with asthma. Arch Pediatr Adolesc Med 2002, 156(6):562-567.

8. Carlton BG, Lucas DO, Ellis EF, Conboy-Ellis K, Shoheiber O, Stempel DA: The status of asthma control and asthma prescribing practices in the United States: results of a large prospective asthma control survey of primary care practices. J Asthma 2005, 42(7):529-535.

9. Lozano P, Finkelstein JA, Hecht J, Shulruff R, Weiss KB: Asthma medication use and disease burden in children in a primary care population. Arch Pediatr Adolesc Med 2003, 157(1):81-88.

10. Krahn MD, Berka C, Langlois P, Detsky AS: Direct and indirect costs of asthma in Canada, 1990. CMAJ 1996, 154(6):821-831.

11. The global strategy for the diagnosis, management and prevention of COPD, Global Initiative for Chronic Obstructive Lung Disease (GOLD). 2014. http://www.goldcopd.org/.

12. McKenzie DK, Abramson M, Crockett AJ, Glasgow N, Jenkins S, McDonald C, Wood- Baker R, Frith PA, on behalf of The Australian Lung Foundation: The COPD-X Plan: Australian and New Zealand Guidelines for the management of Chronic Obstructive Pulmonary Disease 2011. Lutwyche, Queensland: Australian Lung Foundation; 2011 [http://www.copdx.org.au]

13. Ta M, George J: Management of chronic obstructive pulmonary disease in Australia after the publication of national guidelines. Intern Med J 2011, 41:263-270.

14. Mularski RA, Asch SM, Shrank WH, Kerr EA, Setodji CM, Adams JL, Keesey J, McGlynn EA: The quality of obstructive lung disease care for adults in the United States as measured by adherence to recommended processes. Chest 2006, 130:1844-1850.

15. Lavorini F, Magnan A, Dubus JC, Voshaar T, Corbetta L, Broeders M, Dekhuijzen R, Sanchis J, Viejo JL, Barnes P, Corrigan C, Levy M, Crompton GK: Effect of incorrect use of dry powder inhalers on management of patients with asthma and COPD. Respir Med 2008, 102(4):593-604.

16. Melani AS, Bonavia M, Cilenti V, Cinti C, Lodi M, Martucci P, Serra M, Scichilone N, Sestini P, Aliani M, Neiri M: Inhaler mishandling remains common in real life and is associated with reduced disease control. Respir Med 2011, 105(6):930-938. 
17. McGlynn EA, Asch SM, Adams J, Keesey J, Hicks J, Decristofaro A, Kerr EA: The quality of health care delivered to adults in the United States. N Engl J Med 2003, 348(26):2635-2645.

18. Fiks AG: Designing computerized decision support that works for clinicians and families. Curr Probl Pediatr Adolesc Health Care 2011, 41(3):60-88.

19. Perez X, Wisnivesky JP, Lurslurchachai L, Kleinman LC, Kronish IM: Barriers to adherence to COPD guidelines among primary care providers. Respir Med 2012, 106(3):374-381.

20. Grol R, Grimshaw J: From best evidence to best practice: effective implementation of change in patients' care. Lancet 2003, 362(9391):1225-1230.

21. Kawamoto K, Houlihan CA, Balas EA, Lobach DF: Improving clinical decision support systems: a systematic review of trials to identify features critical to success. BMJ 2005, 330(7494):765

22. Osheroff JA, Pifer EA, Teich JM: Improving outcomes with clinical decision support: an implementer's guide. In Chicago: Healthcare Information and Management Systems Society (HIMSS); 2005. http://www. healthinformaticsforum.com/page/component-6-unit-5-lecture-a.

23. Berner ES: Clinical decision support systems: state of the art. AHRQ Publication No. 09-0069EF. In Rockville (MD): Agency for Healthcare Research and Quality; 2009. http://healthit.ahrq.gov/sites/default/files/docs/ page/09-0069-EF_1.pdf

24. Karsh B-T: Clinical practice improvement and redesign: how change in workflow can be supported by clinical decision support. AHRQ Publication No. 09-0054EF. In Agency for Healthcare Research and Quality: Rockville (MD); 2009. http://healthit.ahrq.gov/sites/default/files/docs/page/ 090054 ef.html.

25. Holbrook A, Keshavjee K, Lee H, Bernstein B, Chan D, Thabane L, Gerstein H, Troyan S, COMPETE II Investigators: Individualized electronic decision support and reminders can improve diabetes care in the community. AMIA Annu Symp Proc 2005, 2005:982

26. Holbrook A, Thabane L, Keshavjee K, Dolovich L, Bernstein B, Chan D, Troyan S, Foster G, Gerstein H: Individualized electronic decision support and reminders to improve diabetes care in the community: COMPETE II randomized trial. CMAJ 2009, 181(1-2):37-44.

27. Hicks LS, Sequist TD, Ayanian JZ, Shaykevich S, Fairchild DG, Orav EJ, Bates DW: Impact of computerized decision support on blood pressure management and control: a randomized controlled trial. $J$ Gen Intern Med 2008, 23(4):429-441.

28. Borbolla D, Giunta D, Figar S, Soriano M, Dawidowski A, de Quiros FG: Effectiveness of a chronic disease surveillance systems for blood pressure monitoring. Stud Health Technol Inform 2007, 129(1):223-227.

29. Bertoni $A G$, Bonds DE, Chen H, Hogan P, Crago L, Rosenberger E, Barham $\mathrm{AH}$, Clinch CR, Goff DC Jr: Impact of a multifaceted intervention on cholesterol management in primary care practices: guideline adherence for heart health randomized trial. Arch Intern Med 2009, 169(7):678-686.

30. Gilutz H, Novack L, Shvartzman P, Zelingher J, Bonneh DY, Henkin Y, Maislos M, Peleg R, Liss Z, Rabinowitz G, Vardy D, Zahger D, Ilia R, Leibermann N Porath A: Computerized community cholesterol control (4C): meeting the challenge of secondary prevention. Israel Med Assoc J 2009, 11(1):23-29.

31. Goud R, de Keizer NF, ter Riet G, Wyatt JC, Hasman A, Hellemans IM, Peek N: Effect of guideline based computerised decision support on decision making of multidisciplinary teams: cluster randomised trial in cardiac rehabilitation. BMJ 2009, 338:b1440.

32. Jeffery R, Iserman E, Haynes RB, CDSS Systematic Review Team: Can computerized clinical decision support systems improve diabetes management? A systematic review and meta-analysis. Diabet Med 2013, 30(6):739-745.

33. Roshanov PS, Shika M, Gerstein HC, Garg AX, Sebaldt RJ, Mackay JA, Weise-Kelly L, Navarro T, Wilczynski NL, Haynes RB: Computerized clinical decision support systems for chronic disease management: a decision makerresearcher partnership systematic review. Implement Sci 2011, 6:92.

34. Higgins JPT, Green S: Cochrane Handbook for Systematic Reviews of Interventions Version 5.1.0 The Cochrane Collaboration. In 2011. http://www.cochrane-handbook.org

35. Caroll AE, Anand V, Dugan T, Sheley M, Xu SZ, Down SM: Increased physician diagnosis of asthma with the child health improvement through computer automation decision support system. Pediatr Allergy Immunol 2012, 25(3):168-171.

36. Hashimoto S, Brinke AT, Roldaan AC, van Veen $I H$, Möller GM, Sont JK, Weersink EJ, van der Zee JS, Braunstahl GJ, Zwinderman AH, Sterk PJ, Be
EH: Internet-based tapering of oral corticosteroids in severe asthma: a pragmatic randomised controlled trial. Thorax 2011, 66(6):514-520.

37. Van der Meer V, Bakker MJ, van den Hout WB, Rabe KF, Sterk PJ, Kievit J, Assendelft WJ, Sont JK, SMASHING (Self-Management in Asthma Supported by Hospitals, ICT, Nurses and General Practitioners) Study Group: Internetbased self-management plus education compared with usual care in asthma: a randomized trial. Ann Intern Med 2009, 151(2):110-120.

38. Van der Meer V, van Stel HF, Bakker MJ, Roldaan AC, Assendelft WJ, Sterk PJ, Rabe KF, Sont JK, SMASHING (Self-Management of Asthma Supported by Hospitals, ICT, Nurses and General practitioners) Study Group: Weekly self-monitoring and treatment adjustment benefit patients with partly controlled and uncontrolled asthma: an analysis of the SMASHING study. Respir Res 2010, 11:74.

39. Taylor B, Dinh M, Kwok R, Dinh D, Chu M, Tang E: Electronic interface for emergency department management of asthma: a randomized control trial of clinician performance. Emerg Med Australas 2008, 20(1):38-44.

40. Fiks RW, Hunter KF, Localio AR, Grundmeier RW, Bryant-Stephens T, Luberti $A A$, Bell LM, Alessandrini EA: Impact of electronic health record-based alerts on influenza vaccination for children with asthma. Pediatrics 2009, 124(1):159-169.

41. Bell LM, Grundmeier R, Localio R, Zorc J, Fiks AG, Zhang X, Stephens TB, Swietlik $M$, Guevara JP: Electronic health record-based decision support to improve asthma care: a cluster-randomized trial. Pediatrics 2010, 125(4):770-777.

42. Rasmussen LM, Phanareth K, Nolte H, Backer V: Internet-based monitoring of asthma: a long-term, randomized clinical study of 300 asthmatic subjects. J Allergy Clin Immunol 2005, 115(6):1137-1142

43. Dexheimer JW, Abramo TJ, Arnold DH, Johnson KB, Shyr Y, Ye F, Fan KH, Patel N, Aronsky D: An asthma management system in a pediatric emergency department. Int J Med Inform 2013, 82(4):230-238.

44. Smith JR, Noble MJ, Musgrave S, Murdoch J, Price GM, Barton GR, Windley J, Holland R, Harrison BD, Howe A, Price DB, Harvey I, Wilson AM: The at-risk registers in severe asthma (ARRISA) study: a cluster-randomised controlled trial examining effectiveness and costs in primary care. Thorax 2012, 67(12):1052-1060.

45. Kattan M, Crain EF, Steinbach S, Visness CM, Walter M, Stout JW, Evans R III, Smartt E, Gruchalla RS, Morgan WJ, O'Connor GT, Mitchell HE: A randomized clinical trial of clinician feedback to improve quality of care for inner-city children with asthma. Pediatrics 2006, 117(6):1095-1103.

46. Tierney WM, Overhage JM, Murray MD, Harris LE, Zhou XH, Eckert GJ, Smith FE, Nienaber N, McDonald CJ, Wolinsky FD: Can computer-generated evidence-based care suggestions enhance evidence-based management of asthma and chronic obstructive pulmonary disease? A randomized, controlled trial. Health Serv Res 2005, 40(2):477-497.

47. Martens JD, van der Aa A, Panis B, van der Weijden T, Winkens RA, Severens JL: Design and evaluation of a computer reminder system to improve prescribing behaviour of GPs. Stud Health Technol Inform 2006, 124:617-623.

48. Martens JD, van der Weijden T, Severens JL, de Clercq PA, de Bruijn DP, Kester AD, Winkens RA: The effect of computer reminders on GPs' prescribing behaviour: a cluster-randomised trial. Int J Med Inform 2007, 76(3):403-416

49. Martens JD, van der Weijden T, Winkens RA, Kester AD, Geerts PJ, Evers SM Severens JL: Feasibility and acceptability of a computerised system with automated reminders for prescribing behaviour in primary care. Int $J$ Med Inform 2008, 77(3):199-207.

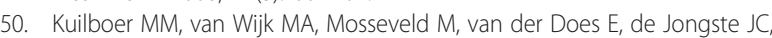
Overbeek SE, Ponsioen B, van der Lei J: Computed critiquing integrated into daily clinical practice affects physicians behaviour- a randomized clinical trial with AsthmaCritic. Methods Inf Med 2006, 45(4):447-454.

51. Poels PJ, Schermer TR, Schellekens DP, Akkermans RP, de Vries Robbé PF, Kaplan A, Bottema BJ, van Weel C: Impact of a spirometry expert system on general practitioners' decision making. Eur Respir 2008, 31(1):84-92.

52. Poels PJ, Schermer TR, Thoonen BP, Jacobs JE, Akkermans RP, de Vries Robbé PF, Quanjer PH, Bottema BJ, van Weel C: Spirometry expert support in family practice: a cluster randomised trial. Prim Care Respir J 2009, 18(3):189-197.

53. Frickton J, Rindal DB, Rush W, Flottemesch T, Vazquez G, Thoele MJ, Durand E, Enstad C, Rhodus N: The effect of electronic health records on the use of clinical care guidelines for patients with medically complex conditions. J Am Dent Assoc 2011, 142(10):1133-1142.

54. Bright TJ, Wong A, Dhurjati R, Bristow E, Bastian L, Coeytaux RR, Samsa G, Hasselblad V, Williams JW, Musty MD, Wing L, Kendrick AS, Sanders GD, 
Lobach D: Effect of clinical decision-support systems a systematic review. Ann of Intern Med 2012, 157(1):29-43.

55. Moher D, Liberati A, Tetzlaff J, Altman DG, PRISMA Group: Preferred reporting items for systematic reviews and meta-analyses: the PRISMA statement. BMJ 2009, 339:b2535.

56. Kesselheim AS, Cresswell K, Phansalkar S, Bates DW, Sheikh A: Clinical decision support systems could be modified to reduce "alert fatigue" while still minimizing the risk of litigation. Health Aff (Millwood) 2011, 30(12):2310-2317.

57. Weingart SN, Toth M, Sands DZ, Aronson MD, Davis RB, Phillips RS Physicians' decisions to override computerized drug alerts in primary care. Arch Intern Med 2003, 163(21):2625-2631.

58. Isaac T, Weissman JS, Davis RB, Massagli M, Cyrulik A, Sands DZ, Weingart SN: Overrides of medication alerts in ambulatory care. Arch Intern Med 2009, 169(3):305-311.

59. Van Der Sijs H, Aarts J, Vulto A, Berg M: Overriding of drug safety alerts in computerized physician order entry. J Am Med Inform Assoc 2006, 13(2):138-147.

60. Roshanov PS, Fernandes N, Wilczynski JM, Hemens BJ, You JJ, Handler SM, Nieuwlaat R, Souza NM, Beyene J, Van Spall HGC, Garg AX, Haynes RB: Features of effective computerised clinical decision support systems: meta-regression of 162 randomised trials. BMJ 2013, 346:657.

61. Bryan C, Boren SA: The use and effectiveness of electronic clinical decision support tools in the ambulatory/primary care setting: a systematic review of the literature. Informatics Prim Care 2008, 16(2):79-91.

62. Kastner M, Straus SE: Clinical decision support tools for osteoporosis disease management: a systematic review of randomized controlled trials. J Gen Intern Med 2008, 23(12):2095-2105.

63. Anchala R, Pinto MP, Shroufi A, Chowdhury R, Sanderson J, Johnson L, Blanco P, Prabhakaran D, Franco OH: The role of Decision Support System (DSS) in prevention of cardiovascular disease: a systematic review and meta-analysis. PLoS One 2012, 7(10):e47064.

64. Buntin MB, Burke MF, Hoaglin MC, Blumenthal D: The benefits of health information technology: a review of the recent literature shows predominantly positive results. Health Aff (Millwood) 2011, 30(3):464-471.

doi:10.1186/1471-2466-14-189

Cite this article as: Fathima et al:: Effectiveness of computerized clinical decision support systems for asthma and chronic obstructive pulmonary disease in primary care: a systematic review. BMC Pulmonary Medicine 2014 14:189

\section{Submit your next manuscript to BioMed Central and take full advantage of:}

- Convenient online submission

- Thorough peer review

- No space constraints or color figure charges

- Immediate publication on acceptance

- Inclusion in PubMed, CAS, Scopus and Google Scholar

- Research which is freely available for redistribution 